\title{
算 ，料
}

\section{ロケットチャンバ用超高張力鋼とその溶接*}

\author{
鈴木和久** 下山仁一** \\ Ultra-High-Strength Steels for Rocket Chambers \\ and Welding of their Steels*
}

By Kazuhisa Suzuki** and Toshikazu Shimoyama**

\section{1.まえがき}

ロケットチャンバ用超高張力鋼の研究は，宇宙開発の 一部門として近年わが国を含め各国で活発に行なわれて おり, 種々のロケットチャンバ用超高張力銓力開発され た。とくに米国における開発研究は著しいものがあり， 次々に新しい材料が開発され，実用化されている.

ロケットチャンバに最も要求される問題は重量の㪕減 化であり，そのために強度/密度比が离くかつ荷重条件 が苛酷であるためにじん性の高い材料でしか子加工性, 溶接性が良い材料が必要である。

わが国における宇宙開発は, 東京大学宇宙航空研究所 が主体上なり推進されてき，ロケットチャンバ用超高 張力鋼の開発は，肎笛開発の一端として東京大学宇宙航 空研究所亡三菱重工業株式会社神局研究所, 神戸造船所 が一体となり， $85 \mathrm{~kg} / \mathrm{mm}^{2}, 100 \mathrm{~kg} / \mathrm{mm}^{2}, 150 \mathrm{~kg} / \mathrm{mm}^{2}$, $200 \mathrm{~kg} / \mathrm{mm}^{2}$ 級の超高張力鋼を次々に開発し, 実用化し てきた。

本稿では，筆者らが行なったロケットチャンバ用超高 張力鋼に関する一連の開発研究結果を主体にして, 超高 張力鋼の諸特性，溶接性および溶接施工，小型チャンバ の压壊試験結果などについてのべる。

\section{2、わが国における開発経過 と現状}

わが国において製作され，打上げられた東京大学宇宙 航空研究所の観測用口ケットでロケットチャンバに高張 力鋼, 超高張力鋼の溶接構造力゙採用されたのは $\mathrm{K}-7$ 型 ロケット以後のむのである，図一1にわが国で打上げら れた観測用口ケットと現在開発中の人工衛星打上げ用 $\mathbf{M}$

* 原稿受付 昭和 40 年 7 月 5 日

** 正員 三落重工業 KK K技術本部神戸研究所 Member, Kobe Technical Institute Mitsubishi Heavy Industries Ltd.
型口ケットの概略図を示す.

K-型ロケットの第 1 段ブースタ（直径 $420 \mathrm{~mm} \phi ） に$ は, $85 \mathrm{~kg} / \mathrm{mm}^{2}$ 級の高張力鐥が最初に使用され，その 当時では（昭和34年度）わが国においてもっとも強度の

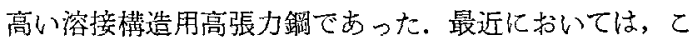
の $\mathrm{K}$-型ロケットの第1段プースタには，100 kg/ $\mathrm{mm}^{2}$

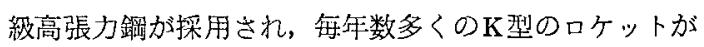
打上げられている。

L一型ロケットの第 1 段ブースタ（直径 $735 \mathrm{~mm} \emptyset$ ）に は $100 \mathrm{~kg} / \mathrm{mm}^{2}$ 級高張力鋼が応用されており，L-3 型 1 号口ケットの第 3 段目には，わが国で最初に $150 \mathrm{~kg} /$ $\mathrm{mm}^{2}$ 級超高張力鋼が使用され，昭和39年 7 月に高度 1000 KM の打上げに成功している。またL-3型3号口ケット の同じく第3段目のチャンバには，同様にわが国で初 に析出硬化型 $200 \mathrm{~kg} / \mathrm{mm}^{2}$ 級超高張力鑶が使用され，昭 利.140年3月に高度 $1040 \mathrm{kM}$ の打上げに成功した。

次に M-型口ヶットは, 東京大学宇宙航空研究所が人 工衛星打上げ用として開発している大型ロケットであ り，そのチャンバに用いられる材料関しては，目下種 々の兒地から検討中である。

このように，わが国に叔りる钼測用ロケットのチャン バに使用される材料は，昭和34年に K-型口ケットに85 $\mathrm{kg} / \mathrm{mm}^{2}$ 級高張力鋼の採用に成功して以来, $100 \mathrm{~kg} / \mathrm{mm}^{2}$ 級高張力鈯, $150 \mathrm{~kg} / \mathrm{mm}^{2}$ 級超高镸力鋼, $200 \mathrm{~kg} / \mathrm{mm}^{2}$ 級超高張力鋼亡次々に強度の高い材料か潤発され，口ケ ットチャンバに応用化され，現時点では $200 \mathrm{~kg} / \mathrm{mm}^{2}$ 級 超高張力鋼の䒠用化に成功をおさぬるまてに発展してい る現状である。

\section{3 . ロケットチャンバ用超高 張力鋼の種類とその特性}

超高張力鋼というとよ゙の程度以上の強度を有する鋼を 
表-1 超高張力銧の化学成分

\begin{tabular}{|c|c|c|c|c|c|c|c|c|c|c|c|c|c|c|}
\hline 型 & 種 & $\mathrm{c}$ & Mn & $\mathrm{Si}$ & $\mathrm{Ni}$ & $\mathrm{Cr}_{r}$ & Mo & $\mathrm{v}$ & Co & $\mathrm{Ti}$ & Al & B & $\mathrm{Zr}$ & Others \\
\hline $\begin{array}{l}\text { 低。合 鉝 } \\
\text { マルテンサイト钢 } \\
\therefore\end{array}$ & $\begin{array}{l}\text { AISI } 4340 \\
\text { AMS } 6434 \\
300 \mathrm{M}\end{array}$ & $\left\{\begin{array}{l}0.38 \sim 0.43 \\
0.31 \sim 0.38 \\
0.41 \sim 0.46\end{array}\right.$ & $\begin{array}{l}.60 \sim 0.80 \\
.60 \sim 0.80 \\
.65 \sim 0.90\end{array}$ & $\begin{array}{l}0.26 \sim 0.35 \\
0.20 \sim 0.35 \\
1.45 \sim 1.80\end{array}$ & $\begin{array}{l}1.65 \sim 2.00 \\
1.65 \sim 2.00 \\
1.65 \sim 2.00\end{array}$ & $\left\{\begin{array}{l}0.70 \sim 0.90 \\
0.65 \sim 0.90 \\
0.70 \sim 0.95\end{array}\right.$ & $\left|\begin{array}{l}0.20 \sim 0.30 \\
0.30 \sim 0.40 \\
0.30 \sim 0.45\end{array}\right|$ & $\begin{array}{c}- \\
0.17 \sim 0.23 \\
\leq 0.05\end{array} \mid$ & $\begin{array}{l}- \\
- \\
-\end{array}$ & - & $\begin{array}{l}- \\
- \\
-\end{array}$ & - & $\begin{array}{l}- \\
- \\
-\end{array}$ & \\
\hline 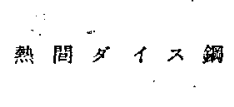 & $\begin{array}{c}\text { H-11 } \\
\text { Vascojet } 1000\end{array}$ & $\mid \begin{array}{c}0.38 \sim 0.43 \\
0.40\end{array}$ & $\begin{array}{c}.20 \sim 0.40 \\
0.30\end{array}$ & $\begin{array}{c}0.80 \sim 1.00 \\
0.90\end{array}$ & - & $\begin{array}{c}4.75 \sim 5.23 \\
5.00\end{array}$ & $\left|\begin{array}{c}1.20 \sim 1.40 \\
1.30\end{array}\right|$ & $\left|\begin{array}{c}0.40 \sim 0.60 \\
0.50\end{array}\right|$ & - & - & - & $\begin{array}{l}- \\
-\end{array}$ & - & \\
\hline $\begin{array}{l}\text { マルテンサイト } \\
\text { ステンレス鋼 }\end{array}$ & $\begin{array}{l}410 \\
419 \\
422\end{array}$ & $\begin{array}{l}\leq 0.15 \\
0.25 \\
0.23\end{array}$ & $\begin{array}{l}\leq 1.00 \\
- \\
0.75\end{array}$ & $\begin{array}{l}\leq 1.00 \\
- \\
0.35\end{array}$ & $\begin{array}{l}- \\
0.5 \\
0.8\end{array}$ & $\begin{array}{c}11.5 \sim 13.5 \\
12.0 \\
12.0\end{array}$ & $\begin{array}{l}- \\
0.5 \\
1.0\end{array}$ & $\begin{array}{c}- \\
0.25 \\
0.25\end{array}$ & $\begin{array}{l}- \\
- \\
-\end{array}$ & $\begin{array}{l}- \\
- \\
-\end{array}$ & $\begin{array}{l}- \\
-\end{array}$ & $\begin{array}{l}- \\
- \\
-\end{array}$ & $\begin{array}{l}- \\
- \\
-\end{array}$ & $\begin{array}{l}3.0 \mathrm{~W} \\
0.10 \mathrm{~N} \\
1.0 \mathrm{~W}\end{array}$ \\
\hline . & $\begin{array}{l}18 \mathrm{Ni}(200) \\
18 \mathrm{Ni}(250)\end{array}$ & $\begin{array}{l}\leq 0.03 \\
\leq 0.03\end{array}$ & $\begin{array}{l}\leq 0.10 \\
\leq 1.10\end{array}$ & $\begin{array}{l}\leq 0.10 \\
\leq 0.10\end{array}$ & $\begin{array}{c}17.0 \sim 19.0 \\
17.0 \sim 19.0\end{array} \mid$ & - & $\begin{array}{l}3.0 \sim 3.5 \\
4.6 \sim 5.1\end{array}$ & - & $\begin{array}{l}8.0 \sim 9.0 \\
7.0 \sim 8.5\end{array}$ & $\begin{array}{l}0.15 \sim 0.25 \\
0.30 \sim 0.50\end{array}$ & $\left|\begin{array}{r}0.05 \sim 0.15 \\
0.05 \sim 0.15\end{array}\right|$ & $\begin{array}{l}0.003 \\
0.003\end{array}$ & $\begin{array}{l}0.02 \\
0.02\end{array}$ & \\
\hline マルニーシング铜 & $\begin{array}{c}18 \mathrm{Ni}(300) \\
20 \mathrm{Ni} \\
25 \mathrm{Ni}\end{array}$ & $\leq 0.03$ & $\leq 0.10$ & $\leq 0.10$ & $\begin{array}{l}18.0 \sim 19.0 \\
18.0 \sim 20.0 \\
25.0 \sim 26.0\end{array} \mid$ & $\begin{array}{l}- \\
- \\
-\end{array}$ & $\begin{array}{c}4.7 \sim 5.2 \\
- \\
-\end{array}$ & $\begin{array}{l}- \\
- \\
-\end{array}$ & $\begin{array}{c}8.5 \sim 9.5 \\
- \\
-\end{array}$ & $\mid \begin{array}{c}0.50 \sim 0.70 \\
1.3 \sim 1.6 \\
1.3 \sim 1.6\end{array}$ & $\left|\begin{array}{l}0.05 \sim 0.15 \\
0.15 \sim 0.35 \\
0.15 \sim 0.35\end{array}\right|$ & 0.003 & 0.02 & $\begin{array}{l}0.3 \sim 0.5 \mathrm{Cb} \\
0.3 \sim 0.5 \mathrm{Cb}\end{array}$ \\
\hline
\end{tabular}




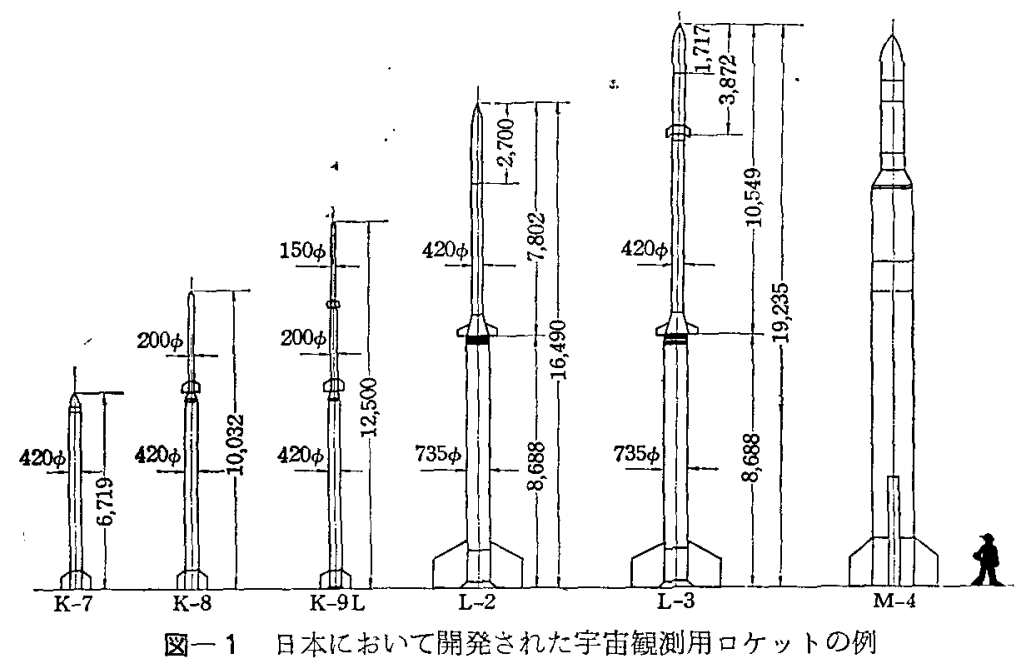

示すかについては, 明確な定義はないが, 現在では大体 引張強さ $100 \mathrm{~kg} / \mathrm{mm}^{2}$ 以上の強度レベルを指すすの上教 えてよいであるう.との強度レベルの鋼の種類を大別す ると, 低合金マルテンサイト鋼 (low-alloy martensitic steel) 熱間ダイス鋸 (hot-work die steel), マルテンサ イトステンレス鋼 (martensitic stainless steel), 析出 硬化ステンレス鋼（precipitation-hardening stainless stee1)、およびマルエージング鎡 (maraging steel) の 5 種類に大別できる。それらの鋼の代表的な化学成分を表 一1に示に示す.

低合金マルテンサイト鋼でロケットチャンバ用として はやくから使用されている屯のはAISI 4340であり, 米 国においては，乙れを基準にして種々改良されてきた。 たとえば AISI 4340 の炭素量を下げた AMS 6434 は Polaris 計画における実験で優秀な成績をおさぬてお り、またInternational Nickel Co.の300 M は AISI 4340 の合金元素量をやや多くし，特に Si 1.45 1.80\% 添加し, 焼庭し抵抗を著しく増加させ切久じん性の改善 を計ったむのである。

熱間ダイス鋼で有名なものは H-11 鎝であり, Vanadium Alloy Co, の Vascojet-1000はロケットチャンバ 用として知られている。この鋼は $400^{\circ} \mathrm{F}\left(204^{\circ} \mathrm{C}\right)$ 以上 の高温強度を要求する場合に優秀な諸性質を示す。

マルテンサイトステンレス釗は AISI 400 系のもので あり, 強度も $150 \mathrm{~kg} / \mathrm{mm}^{2}$ 程度までであり，ロケットチ ゃンバ用に结结とんど使用されない。

析出硬化ステンレス鋼は，航空機工業で広く用いられ てきた材料であり，17-7 pH, 15-7 Mo, 17-4 pH, AM350 などは有名である。こ机らの鋼は，米国において口 ケットチャンバ用に一部使用されているようであるが，
溶接部の後熱処理の複雑さに問題がある.

最後にマルエージング 鋁は， International Nickel Co. で開発された極低炭素一高 $\mathrm{Ni}$ マルテンサイト鋼で あり, $1500^{\circ} \mathrm{F}\left(815^{\circ} \mathrm{C}\right)$ のオースデナイト領域から空冷 することによって形成される低炭素マルテンサイトを時 効処理するととによって著しく強度を上开し得る特性を 有している，表一1に示したようにマルエージング鋼に は，大別する上 $18 \% \mathrm{Ni} ， 20 \% \mathrm{Ni}$ 扰上び $25 \% \mathrm{Ni} の$ 3 種類があり，そのうち $18 \% \mathrm{Ni}$ 系には，その降伏点 が 200,000 psi, 250,000 psi および 300,000 psi 級の 3 種類の鋢種が存する， $18 \% \mathrm{Ni}, 20 \% \mathrm{Ni}$ および $25 \%$ $\mathrm{Ni}$ 鋁はそれぞれ表一 2 k示すようにをの熱処理条件が ととなる、すなわち，18\% Ni は $1500^{\circ} \mathrm{F}\left(815^{\circ} \mathrm{C}\right)$ の才 ーステナイト領域加空冷するととによって室温ですべ てマルテンサイト組織になるが，20\% Ni および 25\% Ni はその条件では室温ではオーステナイトが残留する ために，その後の時効好理のみでは嗤度を上げることが

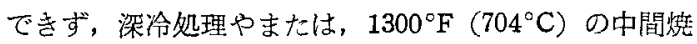
鈍と深冷処理を行ないマルテンサイト組織とする必要が ある.とれからわかる上うに 18\% Ni マルエージング 鋼が熱好理が簡単でロケットチャンバ用としてもうとす

表一2 マルエージング鋼の熱処理

\begin{tabular}{|c|c|c|c|}
\hline 種 䧽 & 热 & 処 & 理 \\
\hline $18 \mathrm{Ni}$ & \multicolumn{3}{|c|}{$1500^{\circ} \mathrm{F}$ 空冷 $\rightarrow 900^{\circ} \mathrm{F} \times 3 \mathrm{Hr}$ 空沼 } \\
\hline $20 \mathrm{Ni}$ & \multicolumn{3}{|c|}{$\begin{array}{l}1500^{\circ} \mathrm{F} \text { 空冷 } \rightarrow-100^{\circ} \mathrm{F} \times 16 \mathrm{Hr} \text { 粱冷知理 } \\
\rightarrow 850^{\circ} \mathrm{F} \times 4 \mathrm{Hr} \text { 空命または } 900^{\circ} \mathrm{F} \times 1 \mathrm{Hr} \text { 冷 }\end{array}$} \\
\hline $25 \mathrm{Ni}$ & \multicolumn{3}{|c|}{ 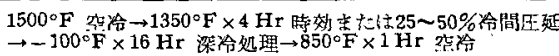 } \\
\hline
\end{tabular}


表一３日本におけるロケットチャンバ用超高張为鎆の化学成分の 1 例

\begin{tabular}{|c|c|c|c|c|c|c|c|c|c|c|c|c|c|c|c|}
\hline 䅤 & $\mathrm{C}$ & $\mathrm{Si}$ & $\mathrm{Mn}$ & $\overline{\mathbf{P}}$ & $\mathrm{s}$ & $\overline{\mathrm{Ni}}$ & $\mathrm{Cr}$ & Mo & $\mathrm{v}$ & $\mathrm{Co}$ & $T i$ & Al & B & $\mathrm{zr}$ & 他 \\
\hline HT- 85 & 0.15 & 0.35 & 1.06 & 0.010 & 0.008 & 0.81 & 0.43 & 0.40 & - & - & - & - & - & - & \\
\hline HV -100 & 0.19 & 0.50 & 1.18 & 0.026 & 0.026 & 1.39 & 0.64 & 0.46 & - & - & $\ldots$ & - & - & - & $.28 \mathrm{Cu}$ \\
\hline HT- $150 \mathrm{~A}$ & 0.34 & 0.31 & 0.73 & 0.015 & 0.015 & 1.82 & 0.85 & 0.35 & 0.24 & - & - & 0.025 & - & - & \\
\hline HT-150B & 0.23 & 1.50 & 0.97 & 0.006 & 0.006 & 1.86 & 0.91 & 0.39 & - & - & - & 0.08 & - & -- & \\
\hline HT -200 & 0.46 & 1.82 & 0.83 & 0.007 & 0.012 & 1.93 & 0.86 & 0.38 & 0.12 & - & - & 0.09 & - & - & \\
\hline $\mathrm{PH}-200$ & $\leq 0.03$ & $\leq 0.10$ & $\leq 0.10$ & $\leq 0.010$ & $\leq 0.010$ & $17 \sim 19$ & - & $4 \sim 6$ & - & $7 \sim 9.5$ & ${ }^{0.30} \sim 0.70$ & $\stackrel{0.05}{\sim 0.15}$ & 0.003 & 0.02 & \\
\hline
\end{tabular}

適しており，米国においてもロケットチャンバとして， 18\% Ni マルエージング鋼が主に採用されているよう である.

以上述べたように，超高張力鋼の種類としては，大別 して5種類があげうろ机るが，ロケットチャンバ用超高張 力鋼として，数多く研究され，加つ害用化されているむ のは，最初にのベた低合金マルテンサイト鋼と鼠終にの べた 18\% Ni マルエージング鋼が主なるあのであろう，

次にわが国におけるロケットチャンバ便用されてい る超高張力墭の種類, 開発経過抢よびそれらの特性につ いてのべる. 表一ろにわが国汇抢けるロケットチャンバ 用超高張力鋼の種類上化学成分を示した. $85 \mathrm{~kg} / \mathrm{mm}^{2}$ 級 高張力鋼 (以下 HT-85 という) はK型ロケットの第

表一 4 HT-85 および HT-100 の機械的性質

\begin{tabular}{|c|c|c|c|c|c|}
\hline 鍓 稙 & $\begin{array}{l}\text { 降 伏点 } \\
\mathrm{kg} / \mathrm{mm}^{2}\end{array}$ & $\begin{array}{c}\text { 引镸強さ } \\
\mathrm{kg} / \mathrm{mm} 2\end{array}$ & 伸\% び & 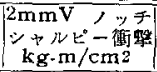 & NTS/TS \\
\hline$H T-85$ & $80 \sim 92$ & $85 \sim 98$ & $\left(\begin{array}{c}14 \sim 24 \\
(\mathrm{GL}=200)\end{array}\right.$ & $\begin{array}{c}8.5 \\
\left(0^{\circ} \mathrm{C}\right)\end{array}$ & $\geq 1.0$ \\
\hline $\mathrm{HT}-100$ & $90 \sim 105$ & $95 \sim 110$ & $\begin{array}{c}12 \sim 16 \\
(\mathrm{GL}=200)\end{array}$ & $\left(\begin{array}{c}4,0 \\
\left(-20^{\circ} \mathrm{C}\right)\end{array}\right.$ & $\geq 1.0$ \\
\hline
\end{tabular}

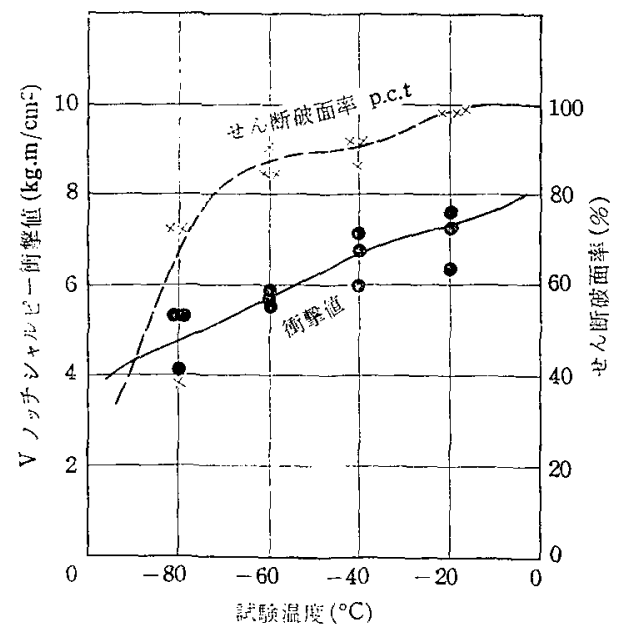

図一2HT100のVノッチシャルピー衝慗試 験結果
1 段ブースタに最初使用された材料であり，最初使 用された昭和34年においては，わが国でもっとも強度の 高い溶接構造用高張力鋼であった。との HT-85 は焼入 れ燒㞍しの熱処理を受けた調質鋼であり，溶接性の点か

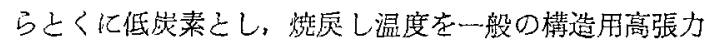
鋼に比べて低くし，岸素当量を下げるように考慮されて いる材料である. $100 \mathrm{~kg} / \mathrm{mm}^{2}$ 級超高張力鋼 (以下 $\mathrm{HT}$ -100 という）はL型口ケットの第 1 段ブースタ用に開 発された材料で HT-85 と同種類の材料であり，HT-8 の合金元菜量をやや增加し，烇戻し温度を考慮して所定 の強度を出すようにした枋料である。とのようにHT-85 および HT-100は T-1 鋼系統の調質高張力鋼である。

表一 4 に HT-85 および HT-100 の機械的性質を， 図一-2に HT-100 の遷移曲線の1例を示す。なお，最 近では，HT-85 の時代は去り，ほ之んど HT-100 がK 型ロケットやL型ロケットの第 2 段ブースタに使用され るようになっている。

次の段階としてわれわれが開発したロケットチャンバ 用超高張力銤は，低合金マルテンサイト超高張力銅》で， 表一 3 亿示したでとく，150 $\mathrm{kg} / \mathrm{mm}^{2}$ 級超高張力鋼では， AMS 6434 を改良した HT-150A, 300 M を低炭素とし た HT-150 B, および $200 \mathrm{~kg} / \mathrm{mm}^{2}$ 級超亳張力鋼では， $300 \mathrm{M}$ 系統の HT-200 について開発研究を進めてきた。 乙の種の超高張力鋼は圧延・焼なまし後加工，溶接し， その後烓入机焼㞔しの調質処理を行って，所定の幾械的 性質を得るものであるが，焼入れ条件としては， 口ケッ トチャンバの上うに板厚が薄い場合，油冷または空冷が 一般的に適用される。これ亿ついて検討した結果, 強度 掠よび延性の点加ら油椧のほうが適していることが明ら かになり2), その場合のオーステナイト化温度を, $870^{\circ} \mathrm{C}$ $\times 1 \mathrm{Hr}$ とした，次にHT-150A，B および HT-200 の烧 庈し条件 (焼戻し温度 $\times 2 \mathrm{Hr}$ 空彾) と強度・延性およ びかたさとの関係を図ー3，4および 5 にそれぞれ示 す.この結果によるとHT-150A と HT-200 は，獟戻し 温度の上昇とともに降伏点, 引張強さ，功たさは低下す るが，HT-150B は引張強さ，加たさは HT-150A お よび HT-200 と同様な傾向を示すが降伙点は 焙戻し温 
度が上暴するにしたがって高くなる傾向を示している。 また伸びは焼居し温度に関係なくはぼ定の值を示して いる.これらの結果から $300^{\circ} \mathrm{C}$ の焼杘しで $150 \mathrm{~kg} / \mathrm{mm}^{2}$ および $200 \mathrm{~kg} / \mathrm{mm}^{2}$ 級の所定の強度が得られるこ上が わかる，図一6および 7 に HT-150A，B と HT-200の $300^{\circ} \mathrm{C}$ 焼戻しの場合の衝撃試験結果を示す。この結果よ

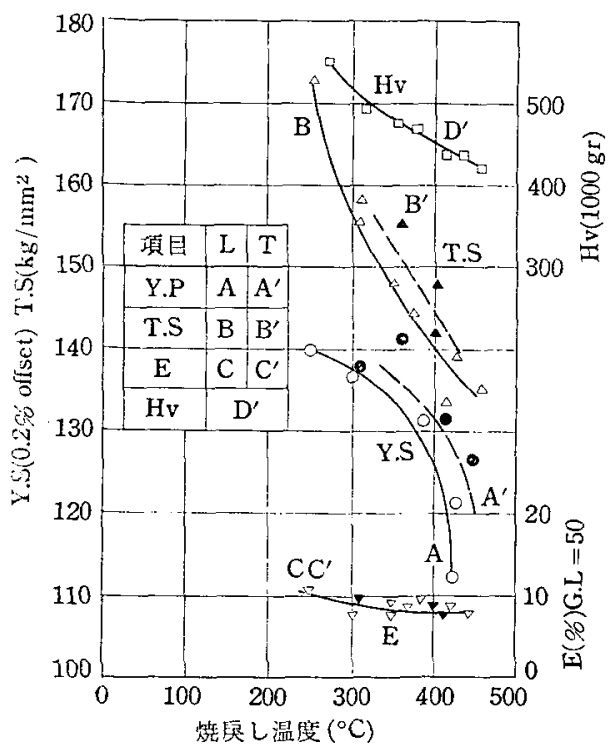

図一 3 HT-150 A の機械的性質に及ぼす焼戻 し温度の影響

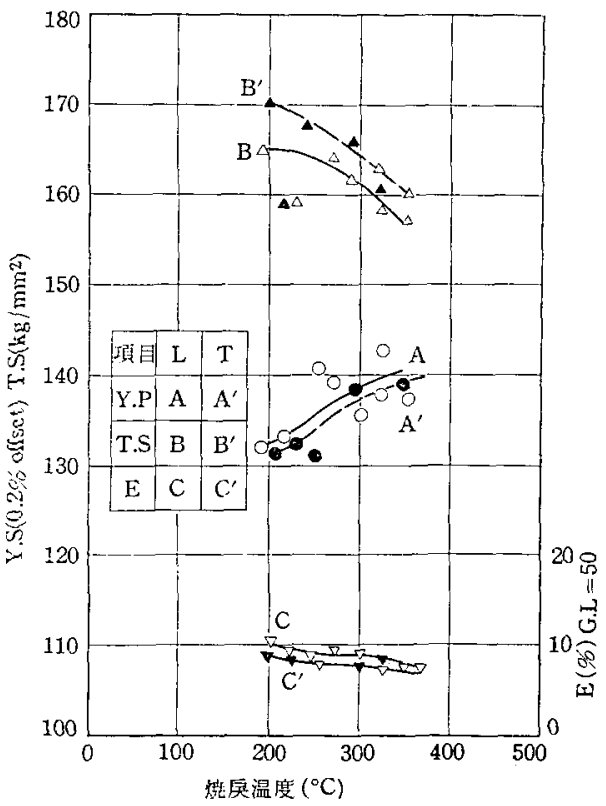

图一 $4 \mathrm{HT}-150 \mathrm{~B}$ の機械的性質に及ぼす焼戻 し渻度の影響

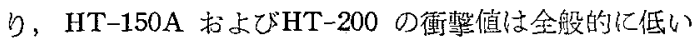
が HT-150B は高いじん性を示しており，300M を改良 し，低炭素亡することにより切欠じん性力改善さ㧈るこ 上がわかる、図一8にこれらの鋼の顕微鏡組織を示すが HT-150B はきわめてチ密な焼苌しマルテンサイト組織 芷呈している.

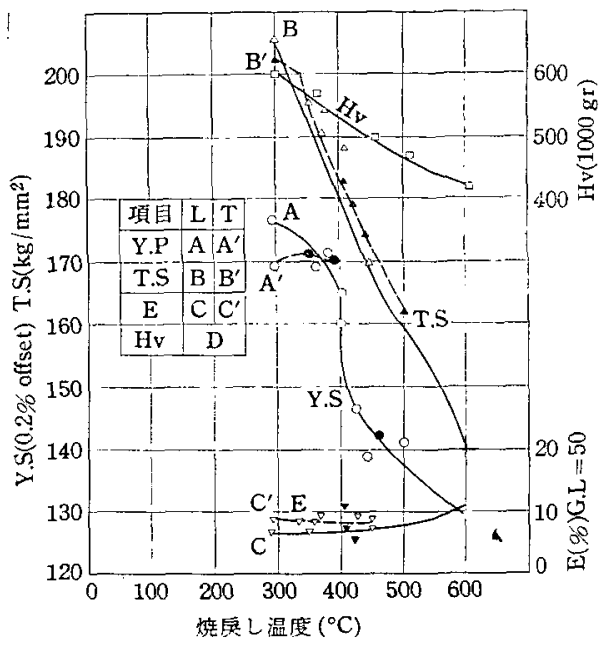

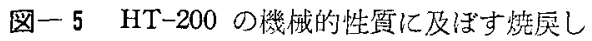
温度の影響

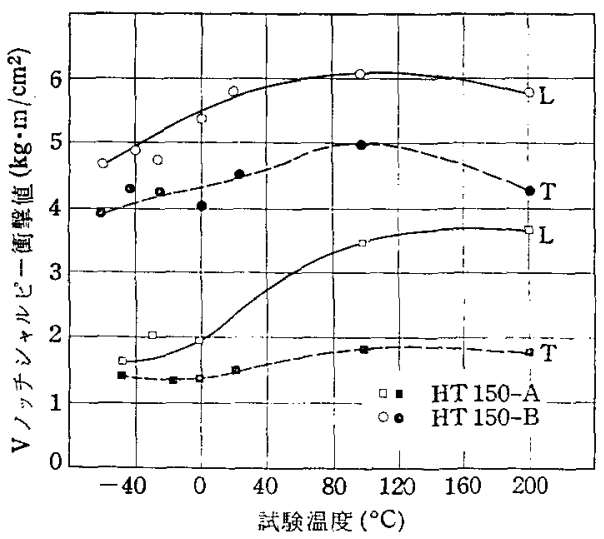

図一 6 HT-150 A および HT-150B の V / ッチシャルピー衝揧試験結果

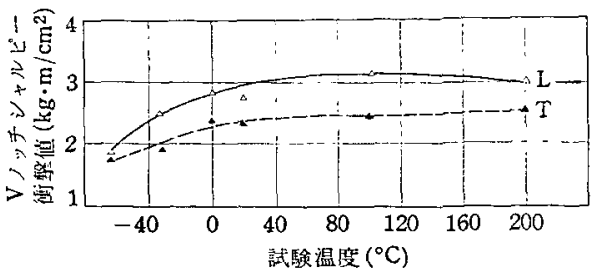

図一 7 HT-200 の V ノッチシャルピー衝揧 試験結果 

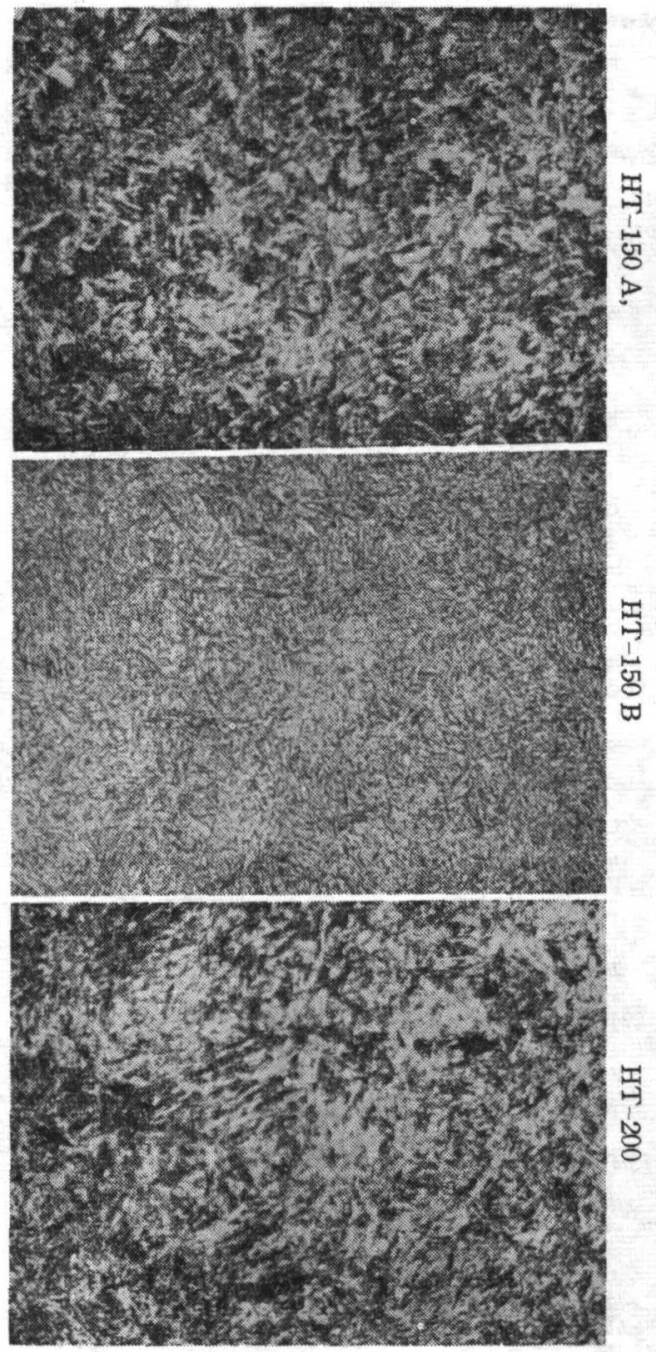

四一8 HT-150 A HT-150 B おおび HT-200 の显微鏡組織 $\left(870^{\circ} \mathrm{C} \times 1 \mathrm{H}\right.$ 油焼入れ, $200 \sim 300^{\circ} \mathrm{C} \times 1 \mathrm{H}$ 焼戾し $\times 400$ )

このように低合金マルテンサイト超高張力鋼において は, 母材の特性上, HT-150 B がすぐ机ており, また, 後でのべる溶接性とモデルチャンバの圧壊試験結果にお いても $150 \mathrm{~kg} / \mathrm{mm}^{2}$ 級としてそん色のない性能を示した ので, わが国におけるロケットチャンバ用低合金マルテ ンサイト超高張力鋼は，300 M を改良した HT150B が 使用されるようになり，前にのべたように L-3 型 1 号 ロケットの第 3 段目のチャンバ（直径 $420 \mathrm{~mm} \phi)$ に始め て採用された。

低合金マルテンサイト $200 \mathrm{~kg} / \mathrm{mm}^{2}$ 級超高張力鎘 $\mathrm{HT}$ -200については，後でのべるようにモデルチャンバの 圧壊試験によって, $200 \mathrm{~kg} / \mathrm{mm}^{2}$ 級の性能を得るととが むつかしいことがわかったので, 低合金マルテンサイト
に代る超高張力鋼の開発を進めた. その結果 表一 3 に 示した析出硬化型 $200 \mathrm{~kg} / \mathrm{mm}^{2}$ 級超高張力鋼 (以下 $\mathrm{PH}$ -200 亡云う) の試作と実用化に成功した ${ }^{3)}$. この PH200 は, 米国の International Nickel Co. か開発した $18 \% \mathrm{Ni}$ マルエージング鋼に相当する超高張力鋼であ り, その化学成分は, 低炭素, 低 $\mathrm{Si}$, 低 $\mathrm{Mn}, \mathrm{Ni} 17$ $19 \%$, Co $7 \sim 9.5 \%$, Mo $4 \sim 6 \%$, Ti $0.3 \sim 0.7 \%$, Al 0.05 〜 $0.15 \%$ である. この鋼種の特徴は, 加工性, 溶接性が きわめて良好で，とくに熱処理が簡単であるために，千 +ンバに製作後油焼入れ焼戻しする低合金マルテンサイ 卜超高張力鋼のような変形および脱炭の問題はなく, 成 形後時效処理 $\left(420 \sim 510^{\circ} \mathrm{C} \times 3 \mathrm{Hr}\right.$ 空冷) によって簡単に 高強度が得られるので，ロケットチャンバ用超高張力鋼 として現在ではすっとあ適しているものと云えよう，以 下この種の超高張力鋼の特性をのべる.

PH-200 の変態点を測定した結果を図ー9に示すが, 温度上昇時には約 $530^{\circ} \mathrm{C}$ から $\alpha \rightarrow r$ への変態を開始

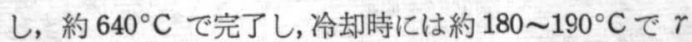
$\rightarrow \alpha へ の$ 変態を開始する. これはオーステナイトからマ ルテンサイトへ変態する $\mathrm{Ms}$ 点であり, 室温ではほぽ全 てマルテンサイト組織となる. このように，オーステナ イト領域で添加元素を十分固溶させ, その後の冷却によ りマルテンサイトにし，時効処理によってマルテンサ1 ト地に金屬間化合物を析出させ強度を上げるととを特徵 としているが, その強度は, 化学成分, 時効処理条件に よって著しく左右される，オーステナイト化の温度は $800 \sim 880^{\circ} \mathrm{C} \times 1 \mathrm{Hr}$ が適しており $900^{\circ} \mathrm{C}$ 以上になると, 結晶粒が粗大化してじん性が低下する. そのために標準

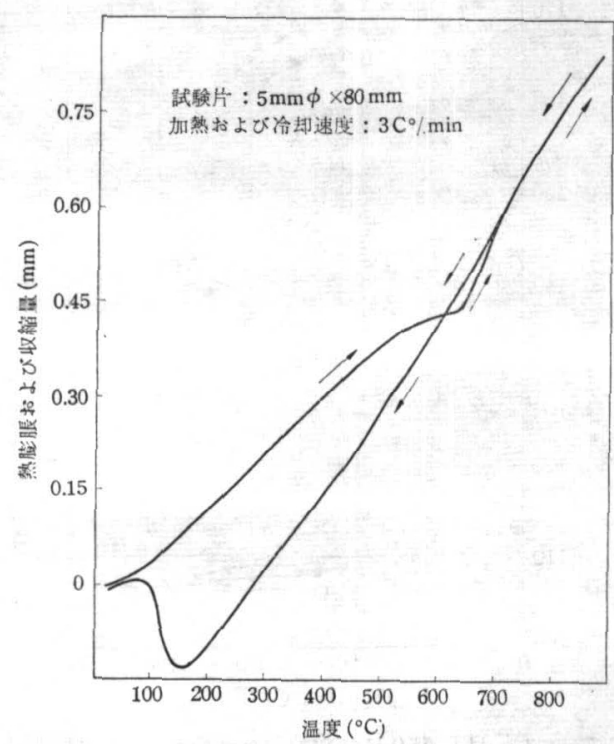

図一 9 PH-200 の変態点測定結果 
のオーステナイト化の温度は $820^{\circ} \mathrm{C} \times 1 \mathrm{Hr}$ とした，て の場合の時効温度（保持時間 $3 \mathrm{Hr}$ ) 之引張強さとの関 係を図一10亿示す。乙れからわかるように時效温度 480 〜 505ㅇ Cでその強度が最高になり，さらに温度を上げる 之強度が低下する傾向がわかる．また保持時間の影響に ついて時効温度 $480^{\circ} \mathrm{C}$ で保持時間と倨㡎さとの関係 を図一11に示す。これより保持時間 $3 \mathrm{Hr}$ で時效効果を 十分だすとよができる。これらのととから PH-200 の標 準熱処理条件は $820^{\circ} \mathrm{C} \times 1 \mathrm{Hr}$ - 空冷, $480^{\circ} \mathrm{C} \times 3 \mathrm{Hr}$ - 空 冷であることが確認でき，米国における $18 \% \mathrm{Ni}$ マルエ ージング鋼の標準熱処理条件と一致することを確めた。

次に化学成分之の関係については，まだ明確な関係は つかまれていないが，H.R. Smith4) らによると Co+4 $\mathrm{Mo}+10 \mathrm{Ti}$ 上降伏点とが相互関係があることを明らかに している. その結果を図一12に示す.

このように PH-200 の機珹的性質は，化学成分上時 效処理条件によって左右されるが，標準的な機械的性質 の範国走示与と，表一 5 のごとく；降伏点 $160 \sim 210 \mathrm{~kg}$ $/ \mathrm{mm}^{2}$, 引張強さ $180 \sim 220 \mathrm{~kg} / \mathrm{mm}^{2}$, 伸び 4 〜13\%の範 国に入り，また超高張力鋼で問題之なる切久感受性をあ らわす NTS/TS. (NTS : NASA の切欠引張試験にお ける切久引張強さ, TS : 平滑材に上り引張強さ)は, 強

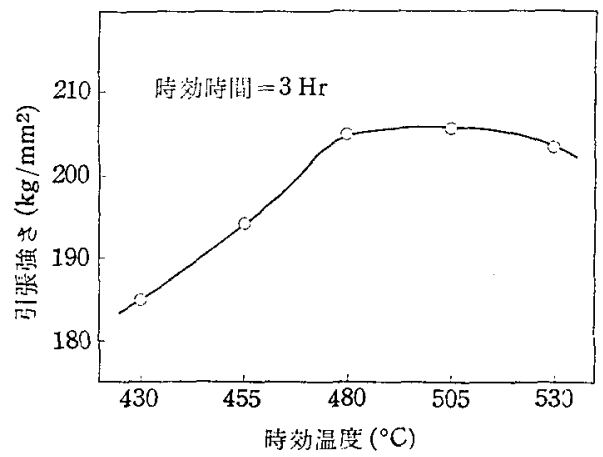

図一10 PH-200 の引張強さに及ぽす時效温度 の影響

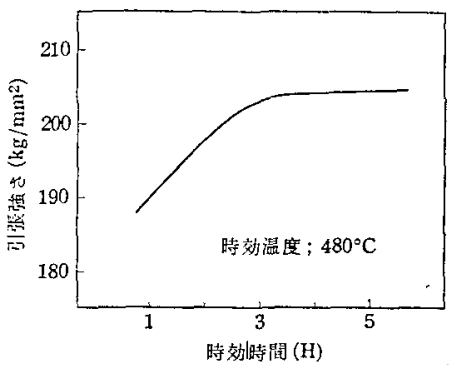

図一-11 HT-200 の引張強さに及ぼす 時効時䦓の影響
表一 5 PH-200 の機械的性質

\begin{tabular}{|c|c|c|c|c|c|}
\hline 铜 種 & $\begin{array}{l}\text { 降 伏点 } \\
\mathrm{kg} / \mathrm{mm}^{2}\end{array}$ & $\begin{array}{l}\text { 引張強さ } \\
\mathrm{kg} / \mathrm{mm}^{2}\end{array}$ & 伸 $\%$ び & NTS/TS & $\begin{array}{l}\text { 二蟿引張強さ } \\
\mathrm{kg} / \mathrm{mm}^{2}\end{array}$ \\
\hline $\mathrm{PH}-200$ & $160 \sim 210$ & $180 \sim 220$ & $\begin{array}{c}4 \sim 13 \\
(\mathrm{GL}=50)\end{array}$ & $0.5 \sim 0.8$ & $190 \sim 225$ \\
\hline
\end{tabular}

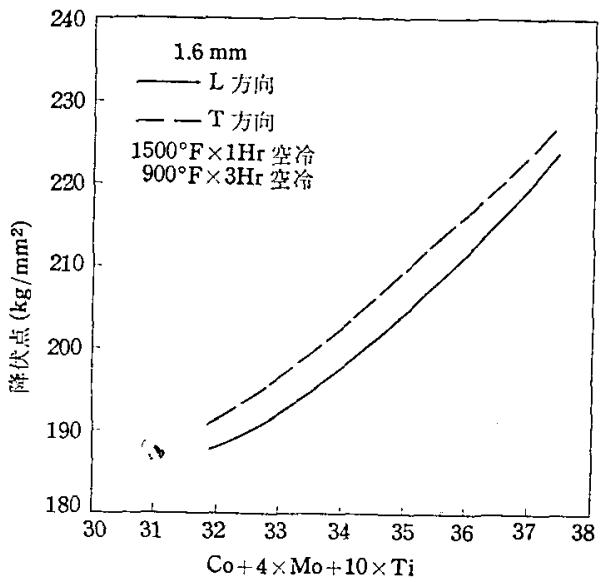

困一12 18\% Ni マルエージング鋼の降伏点之 化学成分との関係

度レベルによってことなるが，0.5〜0.8 の範团の值を示 す、また口ケットチャンバのごとき軘方向と阴周方向と の二軸応力を受ける場合の二軸引張強さ（スリット型引 張試験片）は単軸引張強さ以上の強度を有している．表 一 5 に示してようにての鍓の強度の範囲は広いが，てれ についてはロケットチャンバの種類，板厚，設計条件な どにより，化学成分之熱观理条件を決定しなければなら ない問題である。

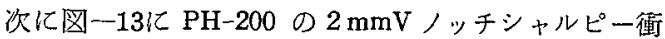
揧試験結果の1例を示す，衝整特性も鋼の強度レベルに よってととなってくるが， $0^{\circ} \mathrm{C}$ において $2.1 \mathrm{~kg} \cdot \mathrm{m} / \mathrm{cm}^{2}$ 以上の衝整値を有し，一般の鋼に見られるような遷移現 象は $300^{\circ} \mathrm{C}$ から $-100^{\circ} \mathrm{C}$ の範囲では見られない。

$200 \mathrm{~kg} / \mathrm{mm}^{2}$ 級超高張力鋼になると，切欠感受性が著 しく高くなり，母材中に含まれる微小欠陷（介在物, 表面

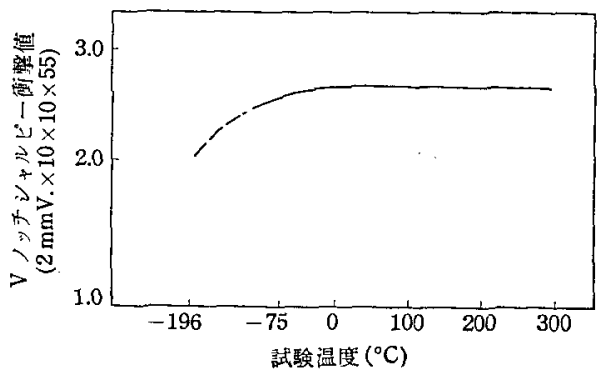

図一13 PH-200 のV/ッチシャルピー衝整 試験結果 
久陌なよ゙）の影響で降伏点よりすはるかに低い応力で破 壞する現象、すなわち不安定破壊 (unstable fracture) が生じる、この超高張力鉿の不安定破壊の特性京調べる ために ASTM (アメリカ材料試験協会) が提案してい る切久引張試駰ら)(篗者ら结侧面切久試験片を用いた）を 行ない PH-200 の破壇じん性 (fracture toughness) を 調べた。この破罣じん性をあらわすパラメータとして， $K_{c}$ 值を求めたが，この $K_{c}$ 值の意味は次のごよきもの である。

$$
\sigma=-\frac{K_{c}}{\sqrt{\pi a}}
$$

ここでは無限に広い板に舆さ $2 a$ の集裂が存在する場 合に不安定破壞が生じる応力であり， $K_{c}$ 値は限界応力 度係数 (critical stress intensity factor) 之云云犯 て挄り, $\mathrm{kg} \cdot \sqrt{\mathrm{mm}} / \mathrm{mm}^{2}$ の dimensionをもっている. この $K_{c}$ 值を簢単に云へば，不安定破壊を生じる笔先 端部にお㚈る局部迌力をらわしていると考え机ばよ W.

図一14亿試験片形状を，表一6に試験結果を一括して 示す.また引張強さと $K_{c}$ 值との関係をプロットすると 図一15のでとくなり，引張強さが高くなるにしたがって $K_{c}$ 值が低下することがわかる。乙のようにして求めた $K_{c}$ 值は，超高張力鍋の材質の判定はもちろんロケット チャンバの設評にも用いられる。すなお，ロケットチ ヤンバの設計に適用する場合の1例として，鼠裂が全板 厚Bを貫通していると仮定し，そのような筴が存在し

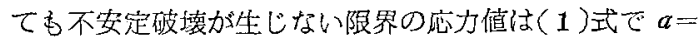
B 己扎いて求めら扎。，その限界の応力值以下で口ケッ チャンバの設計が行なわなければならない。

図-16に PH-200 鋼の高温引張強度特性を示す。听 ットチャンバの場合，とくに第1段ブースタのように空 気密度の高い空間で燃焼する部分は，チャンバ本体と空
気との摩擦によりチャンバの温度が上昇するので, それ を考虑に入れた設計が必要となる.

次に PH-200 鋼の組織についてのベる，図-17に 820 ${ }^{\circ} \mathrm{C} \times 1 \mathrm{Hr}$ 空冷， $480^{\circ} \mathrm{C} \times 3 \mathrm{Hr}$ の時效処理をしたすのと の光学顕微鏡組織を示す。また図一18亿電子顕微鏡組織

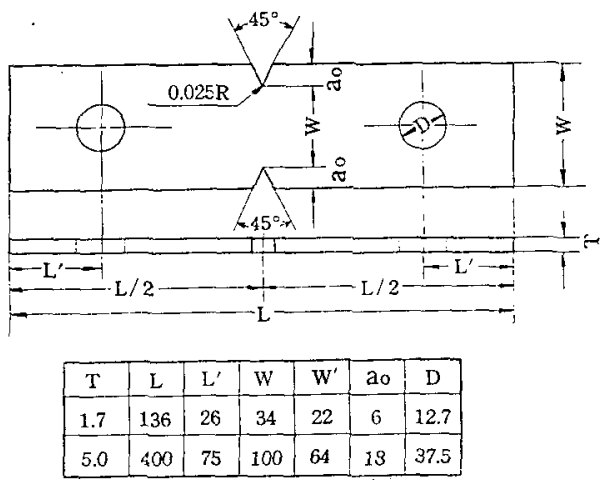

國一14 ASTM 側面切欠試験片

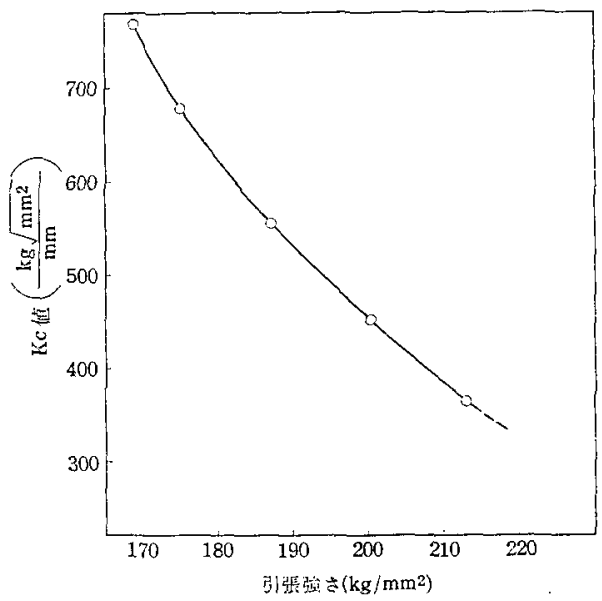

図-15 PH-200 の $K_{c}$ 值と引張強さとの関係

表-6 6 PH-200 $0 \mathrm{Kc}$ 值

\begin{tabular}{|c|c|c|c|c|c|c|c|c|c|c|}
\hline $\begin{array}{c}\sigma \mathrm{y} \\
\left(\mathrm{kg} / \mathrm{mm}^{2}\right)\end{array}$ & $\begin{array}{c}W \\
(m m)\end{array}$ & $\begin{array}{c}\mathbf{T} \\
(\mathrm{mm})\end{array}$ & $\begin{array}{c}\mathrm{a} \\
(\mathrm{mm})\end{array}$ & $\begin{array}{c}\text { 最高荷重 } \\
\text { (kg) }\end{array}$ & $\begin{array}{c}\sigma \mathrm{g} \\
\left(\mathrm{kg} / \mathrm{mm}^{2}\right)\end{array}$ & $(\sigma \mathrm{g} / \sigma \mathrm{y})^{2}$ & $\pi \mathrm{a} / \mathrm{W}$ & $q$ & q $\overline{\mathrm{aw}}$ & $\frac{\mathrm{Kc}}{\mathrm{kg} V \overline{\mathrm{mm}}}$ \\
\hline 196 & 22.00 & 1.00 & 2.98 & 2370 & 107.7 & 0.30 & 0.425 & 0.66 & 3.81 & 410 \\
\hline 196 & 22.00 & 1.04 & 2.98 & 2380 & 104.0 & 0.28 & 0.425 & 0.65 & 3.79 & 394 \\
\hline 194 & 34.05 & 1.87 & 8.85 & 4190 & 65.7 & 0.125 & 0.815 & 1.39 & 6.80 & 447 \\
\hline 194 & 33.95 & 1.83 & 8.20 & 4075 & 65.6 & 0.124 & 0.760 & 1.19 & 6.34 & 416 \\
\hline 179 & 100.0 & 4.96 & 27.08 & 24050 & 48.5 & 0.074 & 0.847 & 1.42 & 1143 & 554 \\
\hline 205 & 100.0 & 6.27 & 22.42 & 22200 & 35.4 & 0.028 & 0.705 & 0.97 & 9.84 & 348 \\
\hline 205 & 100.0 & 6.26 & 20.02 & 25350 & 40.6 & 0.039 & 0.629 & 0.84 & 9.16 & 372 \\
\hline
\end{tabular}

$\sigma \mathrm{y}:$ 酎力

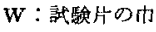

T : " 板厚

a :スロークラックの長ざ

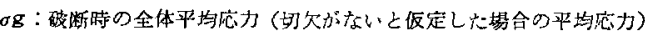




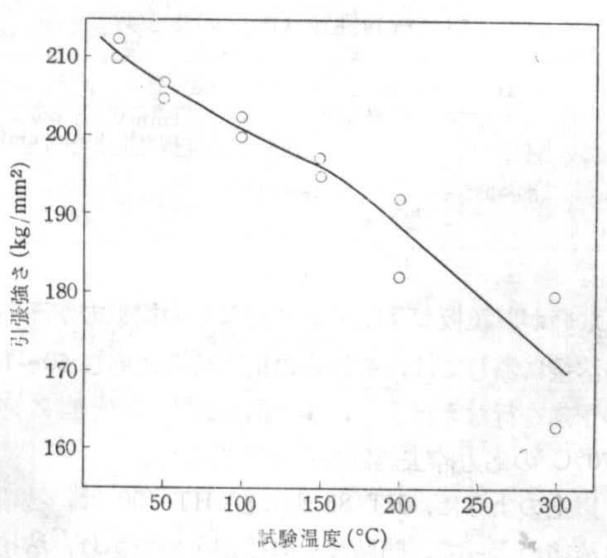

図-16 PH-200 の高温強度

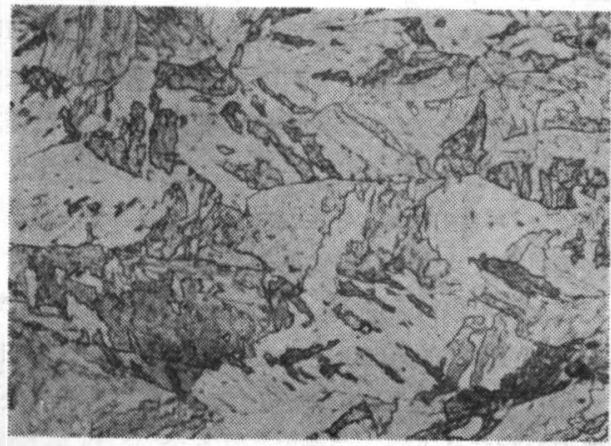

$820^{\circ} \mathrm{C} \times 1 \mathrm{Hr}$ 空冷, $480^{\circ} \mathrm{C} \times 3 \mathrm{Hr}$ 時効処理 図-17 PH-200 の顕微鏡組織 $(\times 500)$

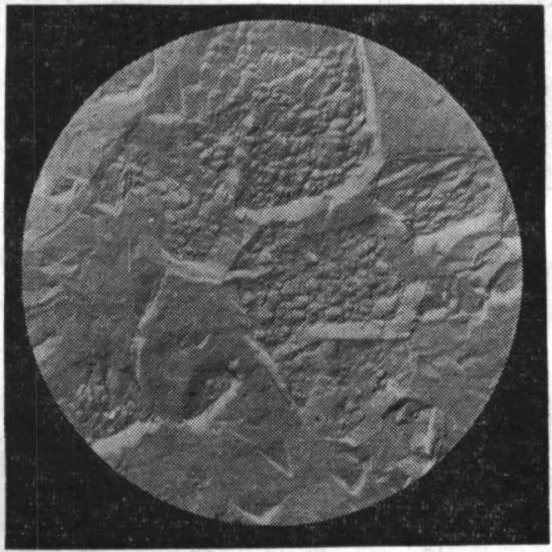

$820^{\circ} \mathrm{C} \times 1 \mathrm{Hr}$ 空冷
（×5,000）を示すが，この程度の倍率では明確に析出物 をとらえることができなかった，析出物の種類について は, 米国における最近の研究では, 金屬間化合物 $\mathrm{Fe}_{3} \mathrm{Mo}$,

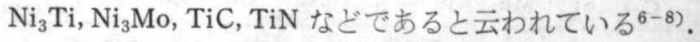

この $18 \% \mathrm{Ni}$ マルェージング鋼に相当する国産の PH -200 は, $200 \mathrm{~kg} / \mathrm{mm}^{2}$ 級超高張力鋼としてその強度特性 と加工性がすぐれており, ロケットチャンバ用としてす でに実用化に入った段階である。

\section{4. ロケットチャンバ用超高 張力鋼の溶接}

\section{4. $185 \mathrm{~kg} / \mathrm{mm}^{2}$ 級高張力鋼および $100 \mathrm{~kg} / \mathrm{mm}^{2}$ 級超高張力鋼の溶接}

HT-85 および HT-100 の溶接は, 一般の溶接構造用 高張力鋼と同様に被覆アーク溶接によって容易に溶接が 可能である. ロケットチャンパの場合には, 板厚が約 2 〜 $6 \mathrm{~mm}$ 程度の薄板であるから, 板厚が $20 \mathrm{~mm}$ 以上に もなる一般の溶接構造物のような溶接熱影㗽部の硬化も 少なく，かつそれに伴なう溶接割れす少ない。

HT-85 に使用される被覆アーク溶接棒は $\mathrm{Mn}-\mathrm{Ni}-\mathrm{Mo}$ 系の低水素系溶接棒であり, 棒径は $2.0,2.4$ および 3.2 $\mathrm{mm} \phi$ が使用される，表一 7 に HT-85 の被覆アーク溶 接棒による全溶着金属の諸性質を，表一 8 に溶接継手の 諸性質をそれぞれ示すが，これらの結果はいずれす層間 温度が $100^{\circ} \mathrm{C}$ 以下の場合である。このように，HT-85 は溶接熱影響部の著しい硬化現象もなく継手の諸性質も すぐれている.

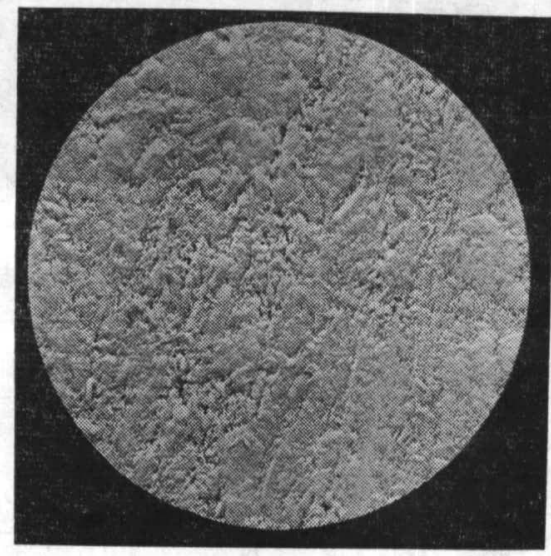

$820^{\circ} \mathrm{C} \times 1 \mathrm{Hr}$ 空冷 $480^{\circ} \mathrm{C} \times 3 \mathrm{Hr}$, 時効処理

図-18 PH-200 の電子顕微鏡組織 $(\times 5000)$ 
表一 7 HT-85 用被蕧アーク溶接の溶着金の化学成分执よび機械的性質（溶接のまま）

\begin{tabular}{|c|c|c|c|c|c|c|c|c|c|c|c|c|}
\hline & & 化 & 学 & 成 & 分 & & & & 做 & 的 & 性 & 簯 \\
\hline $\mathrm{C}$ & $\mathrm{Si}$ & $\mathrm{Mn}$ & $\mathbf{P}$ & $\mathrm{s}$ & $\mathrm{Ni}$ & $\mathrm{Cr}_{\mathbf{r}}$ & Mo & 俛 & $\begin{array}{l}\text { 引張/强 } \\
\mathrm{kg} / \mathrm{m} 2\end{array}$ & 伸 & $\%$ び & 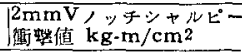 \\
\hline 0.07 & 0.60 & 1.46 & 0.012 & 0.010 & 1.83 & 0.05 & 0.65 & $80 \sim 88$ & $89 \sim 95$ & & $18 \sim 22$ & $\begin{array}{c}9.0 \\
\left(0^{\circ} \mathrm{C}\right)\end{array}$ \\
\hline
\end{tabular}

表一8 HT-85 溶接継手の機械的性質（溶接のまま）

\begin{tabular}{|c|c|c|c|c|c|}
\hline \multirow{2}{*}{$\begin{array}{l}\text { 引镸強さ } \\
\mathrm{kg} / \mathrm{mm} 2\end{array}$} & \multirow{2}{*}{ 曲 げ } & \multicolumn{2}{|c|}{$\begin{array}{l}\mathrm{v} \\
\text { 衝繁缏 } \mathrm{kg} \cdot \mathrm{m} / \mathrm{cm} 2\end{array}$} & \multicolumn{2}{|c|}{$\left(\mathrm{Hv} .{ }^{t} 1 \mathrm{~kg}\right)^{\mathrm{t}}$} \\
\hline & & 溶着金属 & 熟影餐暗 & 渗着金属 & 熱影響部 \\
\hline & $\begin{array}{l}180^{\circ} \\
\operatorname{good}\end{array}$ & $\begin{array}{l}\geq 9.0 \\
\left(0^{\circ} \mathrm{C}\right)\end{array}$ & $\begin{array}{l}\geq 8.0 \\
\left(0^{\circ} \mathrm{C}\right)\end{array}$ & -300 & 300 \\
\hline
\end{tabular}

HT-100 亿使用される被鉂ア一ク溶接棒は， $\mathrm{Mn}-\mathrm{Ni}-$ $\mathrm{Cr}-\mathrm{Mo}$ 系の低水素系溶接棒であり, 溶着金尿の強度之 しては降伏点 $\geqq 90 \mathrm{~kg} / \mathrm{mm}^{2}$, 引張強さ $100 \sim 120 \mathrm{~kg} / \mathrm{mm}^{2}$, 伸び $\geqq 15$ (G.L. $=50 \mathrm{~mm}$ ) を目標として浴接棒を開発し た.表一9に全溶着金屬の諸性質を示す，表一10には，溶 接施工上問題になる予蓺温度および応力除去焼鈍亡継手 の諸性貿との関係を一括してまとめた。これより，150 までの予熱と $570^{\circ} \mathrm{C}$ の応力除去邺鈍を行なっても溶接 継手の性能を確保できることがわかる。また溶接熱影郷 部の最高かたさは，溶接のままでは約 $\mathrm{H}_{\mathrm{V}} 400$ 前後であ り，やや硬化しているが，ロケットチャンバの場合は薄 板であるので一般に拘束力が低いために溶接割れの問題

表-10 HT-100 溶接継可の蒷度

\begin{tabular}{|c|c|c|c|c|c|}
\hline 予 & 熱 温 度 & 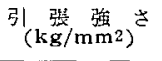 & 破 & 断 位 & 贯 \\
\hline & \multirow{2}{*}{ 熱 新 } & 99.7 & \multirow{2}{*}{ 舟 } & \multirow{2}{*}{\multicolumn{2}{|c|}{ 材 }} \\
\hline & & 100.0 & & & \\
\hline \multirow{2}{*}{\multicolumn{2}{|c|}{$50^{\circ} \mathrm{C}$}} & 104.8 & \multirow{2}{*}{ 坶 } & \multirow{2}{*}{\multicolumn{2}{|c|}{ 材 }} \\
\hline & & 103.0 & & & \\
\hline \multirow{2}{*}{\multicolumn{2}{|c|}{$100^{\circ} \mathrm{C}$}} & 103.0 & \multirow{2}{*}{ 母 } & \multirow{2}{*}{\multicolumn{2}{|c|}{ 材 }} \\
\hline & & 101.9 & & & \\
\hline \multirow{2}{*}{\multicolumn{2}{|c|}{$\begin{array}{c}150^{\circ} \mathrm{C} \\
\vdots\end{array}$}} & 104.9 & \multirow{2}{*}{ 母 } & \multirow{2}{*}{\multicolumn{2}{|c|}{ 材 }} \\
\hline & & 101.3 & & & \\
\hline \multirow{2}{*}{$570^{\circ} \mathrm{C}$} & \multirow{2}{*}{ 空力除去暁敛 } & 98.7 & \multirow{2}{*}{ 溶 } & \multirow{2}{*}{ 接 } & \multirow{2}{*}{ 部 } \\
\hline & & 104.0 & & & \\
\hline
\end{tabular}

はないが，鏡板およびリング材などの拘束力が高い部分 の溶接に際しては，それらの拘束状沉に応じ $50 \sim 150^{\circ} \mathrm{C}$ の予熱を行なえばよく，また溶接部材の状態に応じて $570^{\circ} \mathrm{C}$ の応力除去焼鈍を行なえばよい.

以上のように, HT-85 および HT-100 は, 被得了一 ク溶接によって, 問題なく溶接が可能であり, 溶接のま まで溶接部の性能を十分に出すことができる。

\section{2 低金合マルテンサイト超高張力鋼の溶接}

$150 \sim 200 \mathrm{~kg} / \mathrm{mm}^{2}$ 級低合金マアルテンサイト超高張力 鍓は，焼入れ㸁戻しの熱好理によって，引張強さ 150〜 $200 \mathrm{~kg} / \mathrm{mm}^{2}$ の強度を出すものであり, 溶接継手に対し ても母材と同等の強度が要求される，しかし，溶接のま までこの程度の強度を出すととは，母材の特性上からも 溶着金屬の特性上からあきわかて园難であり，必然的に 溶接後に焼入れ燃杘しの熱好理を行なおなり机ばならな

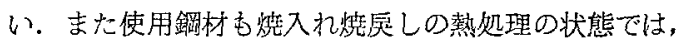
加たさが $\mathrm{H}_{\mathrm{V}}$ 500 600 となり, 冷間加工, 機械加工が むつかしく, そのために軟かい状態で加工を終了後, 調 質処埋を行なう工作法が採用される。

\section{2 .1 溶接方法扎上び溶接材料}

低合金マルテンサイト超高張力䥓に適用する溶接方法 としては, 被蕧アーク溶接法, TIG 溶接法, MIG 溶接 法, サブマージドアーク溶接法打よびエレクトロンビー ム溶接法などが一応考えられる。しかし，ロケットチャ ンバのような薄板棈造でしかも溶接部に対して全く欠陷 がなくかつじん性の高いことが要求される場合，MIG溶 接法では，溶接入熱量が必然的に高くなりそれに伴なっ てじん性が低下し，またブローホールなごの久陷も入り やすい. サブマージドアーク溶接法は，MIG溶接法と同 様に溶接入熱量が高くなり，またフラックスの開発が問 題である.エレクトロンビーム溶接は，米国に㧍いては 一部応用されているようであるが，わが国においては， まだそこまでには至っていない。このようなことから，

表一 - HT-100 用被覆アーク溶接の溶着金属の化学成分と機械的性貿·(溶接のまま)

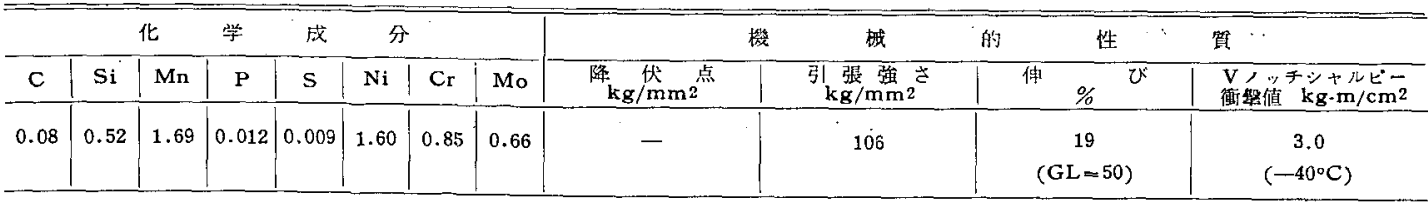


適用できる溶接法としては、被覆アーク溶接法乙 TIG 溶接法が考えられるが, 被覆アーク溶接法では溶接割れ が生じやすく，現状では TIG 溶接法がもっとも適して いる溶接法である。

TIG 溶接に使用するワイヤは，溶接後に䓡処理を行 ない，その状態で母材と溶接部之がほぼ同一な性犋を有 さなければならないために，母材とほほ同成分の共金系 ワイヤを使用することが望ましい.

被覆アーク溶接棒では，基本的には母材と同じ成分系 であるが，ブローホールなどの溶接欠陥を防止するため に, 化学成分の調整が必要である. 表一11に HT-150 お。 よび HT-200 用の被覆アーク溶接棒による全溶接金虽の 諸性質を示す，成分系は C-Si-Mn-Ni-Cr-Mo 系であ り，強度を出すために炭菜量が一般の高張力鋼の溶接金 屬に比べて多くなっている。このためにピット，ブロー ホールが発生しやすい傾向にあり，てれらの久宿を防止 するため Si に量を高くしたすのである。これらの機械 的性質を見ると HT-200 用のるのは，引張強さが 175 $\mathrm{kg} / \mathrm{mm}^{2}$ の值を示し, $200 \mathrm{~kg} / \mathrm{mm}^{2}$ 級の強度には達しな い.これらの結果加ら，溶接久陷のない溶着金尿を得る ためには，低合金系の被㠅アーク溶接棒としては，全溶 着金屬の引張強さが $175 \mathrm{~kg} / \mathrm{mm}^{2}$ 程度が限界ではないか と思われる.な祝，溶接継手になった場合は，母材の影 響が入り， $200 \mathrm{~kg} / \mathrm{mm}^{2}$ 級の強度を出すことは可能であ る.

\section{2 .2 溶接性}

低合金マルテンサイト超高張力䤾の溶接性を考える場 合の問題点は溶接熱影響部の硬化之, 溶接部の割れの問 題であろう。溶接熱影響部の硬化は著しく, $150 \mathrm{~kg} / \mathrm{mm}^{2}$ 級で $\mathrm{H}_{\mathrm{V}} 500 \sim 600,200 \mathrm{~kg} / \mathrm{mm}^{2}$ 級で $\mathrm{H}_{\mathrm{V}} 600 \sim 700$ の かたさを呈する，図一19に表一3に示した HT-150 A, と HT-200 の最高かたさ試験結果を示すが, HT-150 A では予熱温度を上げるに従ってかたさが低下する。しか し HT-200 では，300ㄷ の予熱を行なってるかたさの 低下はほ上んど見られない，乙のように，溶接のままの 状態では，熱影響部は著しく硬化するが溶着金屬も熱影

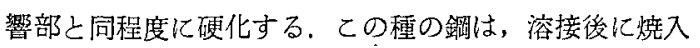

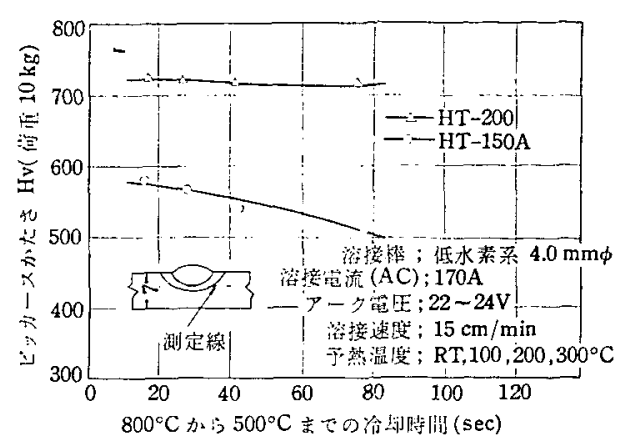

図一19 HT-150A およで HT-200 の HAZ 、
の最高功さ

れ焼戾しの処理をするために溶接部は母材と同程度のか たさ，すなわち $150 \mathrm{~kg} / \mathrm{mm}^{2}$ 級では約 $\mathrm{HV}_{\mathrm{V}} 500,200 \mathrm{~kg}$ $/ \mathrm{mm}^{2}$ 級では約 $\mathrm{H}_{\mathrm{V}} 600$ 上なり，溶接部のかたさが著し く不均一になることはない，このようなととから，溶接 性の面加考える上硬化性それ自体上りも，硬化するこ とにより溶接部の割れ感受性が著しく高くなるというこ との方が重要な問題となる．とくに被覆アーク溶接の場 合，拡散性水素の影響により，溶接割れをおこしやす い. 筆者らが行なった実験によると2)，溶接部に生じる 主な割れは, 約 $100^{\circ} \mathrm{C}$ 以下の温度で生じる典型的な低温 割れであり, 板厚 $7 \mathrm{~mm}$ の場合予熱温度を $200 \sim 300^{\circ} \mathrm{C}$ で溶接してもルート割れを完全に防止することはむつか しい. 溶接割れ防止の点加云うと予熱効果よりむしろ 後熱效果のほうが大きく，例えば予熱なしで溶接し，約 $200^{\circ} \mathrm{C}$ に冷却した時点でバーナにより後熱すると， 150 $\mathrm{kg} / \mathrm{mm}^{2}$ 級では。約 $300^{\circ} \mathrm{C}$ の後熱ではほぼルート制れ を防止することができ; $200 \mathrm{~kg} / \mathrm{mm}^{2}$ 級では，約 $600^{\circ} \mathrm{C}$ の後熱でそれが可能であった.

いっぱうTIG溶接の場合は，被覆アーク溶接のように 拡散性水素の影響が少ないために溶接割れは生じにく く，予熱を行なわなくても薄板の場合は溶接部化割れを はとんご生じない.

超高張力鋼の場合代は，以上の問題の他溶接部の高 温割れについても考虑しなければならない。これはオー

表-11 HT-150 および HT-200 用被覆アーク溶接の溶着金屬の化学成分および幾械的 性質 $\left(870^{\circ} \mathrm{C}\right.$ 油烓入征 $200 \sim 300^{\circ} \mathrm{C}$ 焙戻し)

\begin{tabular}{|c|c|c|c|c|c|c|c|c|c|c|c|c|}
\hline & 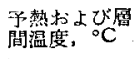 & C & Si & $\mathbf{M n}$ & $P$ & $\mathrm{~s}$ & $\mathrm{Ni}$ & $\mathrm{Cr}$ & Mo & $\begin{array}{l}\text { 引䀠强さ } \\
\mathrm{kg} / \mathrm{mm} 2\end{array}$ & 伸 $\%$ び & 皎 $\%$ \\
\hline $\mathrm{HT}=150$ & 200 & 0.30 & 0.61 & 1.26 & 0.012 & 0.010 & 2.10 & 0.85 & 0.55 & 150.4 & $\begin{array}{c}6.0 \\
(G L=32)\end{array}$ & - \\
\hline $\mathbf{H} \mathbf{T}-200$ & 200 & 0.35 & 1.97 & $1.16^{-}$ & 0.012 & 0.013 & 1.93 & 0.70 & 0.39 & 175.2 & $\begin{array}{c}4.0 \\
(G L=50)\end{array}$ & 14.0 \\
\hline
\end{tabular}


ステナイトの結畾粒界に低融点化合物を形成し高温にお ける延性が低下するためであると云われており，高温割 れを防止するためには，低溶融点化合物を形成方る P,S をできるだけ低くしなりればならない，との $\mathrm{P}, \mathrm{S}$ の限 界としては，P+S $\leqq 0.025 \%$ でしかも $\mathrm{P}, \mathrm{S}$ おのおのが 0.015 以下でなければならないと云われている ${ }^{9,10)}$.

\section{2 .3 溶接継手の性能}

表一 12 に前に表一 3 において示した HT-150 A および $\mathrm{B}$ の溶接継手の機械的性質を，表一13には，同様に HT -200の溶接継手の機械的性質をそれぞれ示した。乙れ らの溶接は，HT-150A および HT-200は, 第 1 的 層 TIG 溶接を行ないそれ以後の層は被㙏ア一ク溶接（ 予熱温度 $200^{\circ} \mathrm{C}$ ) で溶接し, HT-150 B の場合は, 全て TIG 溶接を行なった。表一12および13に示したものは 溶接後 $870^{\circ} \mathrm{C}$ 油焼入れ，200 300 ${ }^{\circ} \mathrm{C}$ 焼戻し処理を行 なったものの機械的性質である，継手强度は，いずれ屯
母材と同程度の強さを示し，また胜げ試験においては， $300 \mathrm{M}$ を改良した HT-150 B が, $150 \mathrm{~kg} / \mathrm{mm}^{2}$ 級とし てきわめて高い延性を有している.

図一20，21および22に HT-150 A，B および HT-200 の溶接部のかたさ分布を示すが，母材と溶接部は，同程 度のかたさを示している，図一-23，24および25に溶接部 の顕微鏡組織を示したが，いずれも低温度で燃戻したマ ルテンサイト組織を是し，上くに $300 \mathrm{M}$ を改良した HT150 B では組織がち密である。

このように 150〜 200 kg/mm² 級低合金マルテンサイ 卜超高張力鋼の溶接継手の静的強度としては，母材と同 程度の特性を有しており, とくに $300 \mathrm{M}$ 改良した HT -150 B の溶接継手の性能は，すぐれた延性を示し，組 織的にもち密なじん性を有する組織を呈しており，後に のベる小型モデルチャンバの压壊試験においてもきわめ てすくれた性能を示した。

表一12 HT-150A および HT-150B の母材および溶接継手の機械的性質

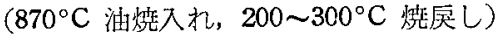

\begin{tabular}{|c|c|c|c|c|c|c|c|c|c|c|c|c|}
\hline \multirow[b]{2}{*}{ 材 } & & \multicolumn{3}{|c|}{ 引 } & \multicolumn{3}{|c|}{ 䮦 } & \multicolumn{3}{|c|}{ 曲 } & 試 & 験 \\
\hline & & 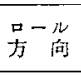 & $\underset{(\mathrm{kg} / \mathrm{mm} 2)}{\mathrm{Y} . \mathrm{S}}$ & $\begin{array}{c}\mathbf{T} \cdot \mathbf{S} \\
\left(\mathbf{k g} / \mathbf{m m}^{2}\right)\end{array}$ & $\begin{array}{c}\mathrm{E} \\
\mathrm{G} \cdot \mathrm{L}=50 \\
(\%)\end{array}$ & $\begin{array}{l}\mathrm{R} . \mathrm{A} \\
(\%)\end{array}$ & $\begin{array}{ll}\text { 破 } & \text { 断 } \\
\text { 位 埴 }\end{array}$ & $\begin{array}{l}\mathrm{P}-ル \\
\text { 方向 }\end{array}$ & & $\begin{array}{c}\text { 角 } \\
(19 \mathrm{R} \times \mathrm{deg} \\
\end{array}$ & $\left(\begin{array}{c}\mathbf{E} \\
\%\end{array}\right)$ & 曲げ状沅 \\
\hline \multirow{4}{*}{ HT-150A } & \multirow{2}{*}{ 专 材 } & $\mathbf{L}$ & $136.9 \sim 139.4$ & $164.3 \sim 165.0$ & 10.0 & $38.3 \sim 41.5$ & & L & & & $\begin{array}{l}37.9-40.0 \\
(\mathrm{GK}=5)\end{array}$ & 割 れ \\
\hline & & $\mathbf{T}$ & $135.4 \sim 139.8$ & $164.0 \sim 164.1$ & $9.0 \sim 9.5$ & $35.2 \sim 38.3$ & & $\mathrm{~T}$ & & & $\begin{array}{l}30.0 \sim 32.0 \\
(G L=5)\end{array}$ & 割 れ \\
\hline & \multirow{2}{*}{ 継 手 } & & & 164.0 & & & 目 忉 & & F.B & $153^{\circ}$ & $\begin{array}{c}23.3 \\
(\mathrm{GL}=6)\end{array}$ & $\begin{array}{l}\text { 容着金䨛部 } \\
\text { b与破断 }\end{array}$ \\
\hline & & & & 163.0 & & & 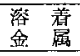 & & R. B & $25^{\circ}$ & $\begin{array}{c}5.0 \\
(\mathrm{GL}-4)\end{array}$ & 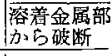 \\
\hline \multirow{4}{*}{$\mathrm{HT}-150 \mathrm{~B}$} & \multirow{2}{*}{ 母 材 } & L & 141.5 & 165.5 & 8.0 & & & & & & & \\
\hline & & $T$ & 132.0 & 167.5 & 7.5 & & & & & & & \\
\hline & \multirow{2}{*}{ 継 手 } & & & 164.1 & & & $\begin{array}{ll}\text { 溶篃 } \\
\text { 金 }\end{array}$ & & F. B & $180^{\circ}$ & & 微小割れ \\
\hline & & & & 163.8 & & & $\begin{array}{ll}\text { 溶 䕊 } \\
\text { 獪 }\end{array}$ & & R. B & $180^{\circ}$ & & $"$ \\
\hline
\end{tabular}

表一13 HT-200 の母材方よび溶接継手の㙨械的性質 $\left(870^{\circ} \mathrm{C}\right.$ 油烧入れ， $200 \sim 300^{\circ} \mathrm{C}$ 绫厌 ()

\begin{tabular}{|c|c|c|c|c|c|c|c|c|c|c|c|}
\hline \multirow[b]{2}{*}{ 材＼cjkstart料 } & & \multicolumn{2}{|r|}{ 引 } & \multicolumn{4}{|c|}{ 験 } & \multicolumn{2}{|c|}{ 曲 } & \multicolumn{2}{|r|}{ 験 } \\
\hline & & $\begin{array}{l}\text { 口-几 } \\
\text { 方何 }\end{array}$ & $\left(\begin{array}{c}\mathrm{Y} \cdot \mathrm{S} \\
\left(\mathrm{kg} / \mathrm{mm}^{2}\right)\end{array}\right.$ & $\underset{\left(\mathbf{k g} / \mathbf{m m}^{2}\right)}{\mathrm{T} \cdot \mathrm{S}}$ & $\begin{array}{c}\mathrm{E} \\
\mathrm{GL}=50 \\
(\%)\end{array}$ & $\underset{(\%)}{\mathrm{R} . \mathrm{A}}$ & $\begin{array}{l}\text { 破 断 } \\
\text { 翯 }\end{array}$ & $\begin{array}{l}\text { 号一ル } \\
\text { 方 向 }\end{array}$ & 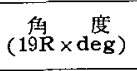 & $\underset{(\%)}{\mathbf{E}}$ & 曲げ状況 \\
\hline \multirow{4}{*}{$\begin{array}{c}\mathbf{H T}-200 \\
\cdots\end{array}$} & \multirow{2}{*}{ 母 材 } & $\mathbf{L}$ & $162.7 \sim 164.5$ & $201.2 \sim 201.8$ & $9.5 \sim 10.0$ & $23.4 \sim 25.0$ & & L & & $\begin{array}{c}22.0 \sim 24.0 \\
(G L=5)\end{array}$ & 割犯 \\
\hline & & $T$ & $167.0 \sim 167.2$ & 201.4 & $9.5 \sim 10.0$ & $25.1 \sim 25.2$ & & $T$ & & $\begin{array}{c}14.0-22.0 \\
(G L=5)\end{array}$ & 割 丸 \\
\hline & \multirow{2}{*}{ 秋手 } & & & 195.3 & & & 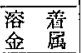 & & $150^{\circ}$ & $\begin{array}{c}21.6 \\
(\mathrm{GL}=6)\end{array}$ & 溶萺金樂部 \\
\hline & & & & 200.0 & & & 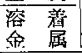 & & $114^{\circ}$ & $(G L=4)$ & 溶箱金属新 \\
\hline
\end{tabular}

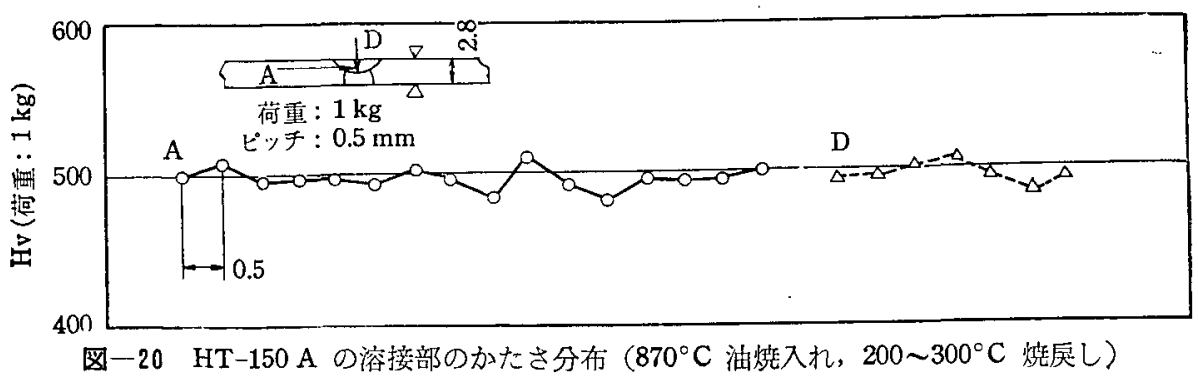




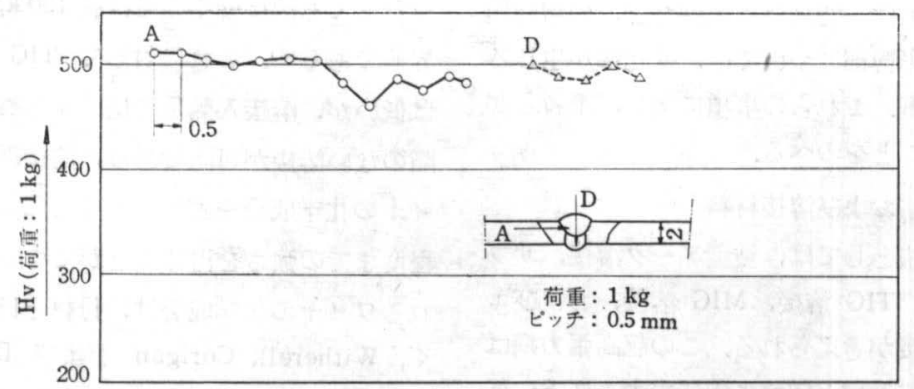

図一21 HT-150 B の溶接部のかたさ分布

$\left(870^{\circ} \mathrm{C}\right.$ 油焼入れ, $200 \sim 300^{\circ} \mathrm{C}$ 焼戻し)

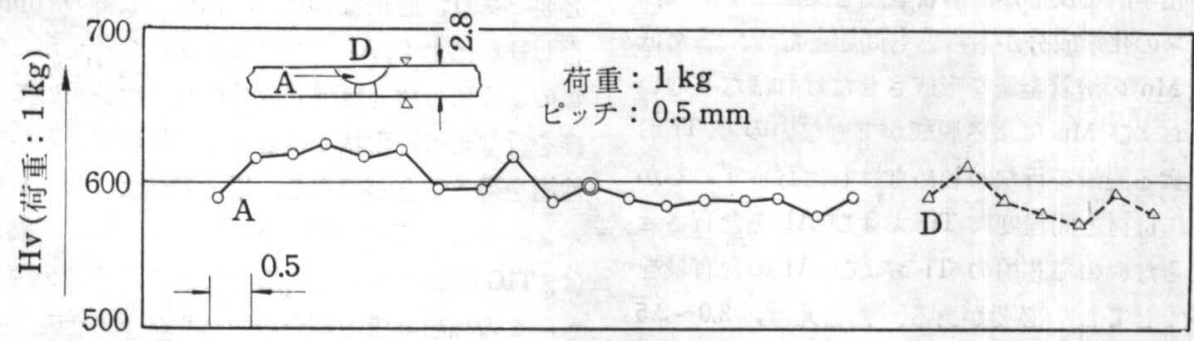

図一22 HT-200 の溶接部のかたさ分布 $\left(870^{\circ} \mathrm{C}\right.$ 油焼入れ, $200 \sim 300^{\circ} \mathrm{C}$ 焼戾し)

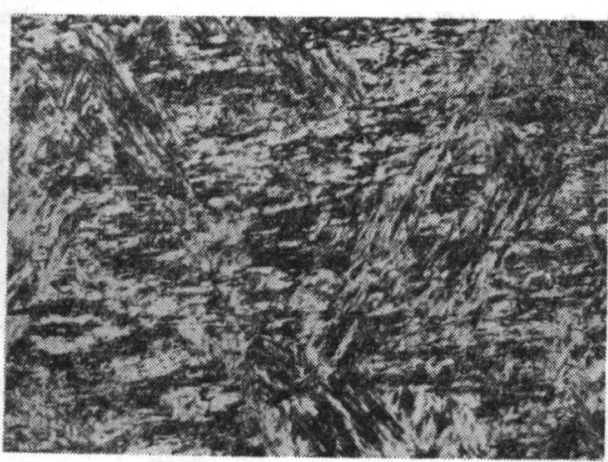

図一23 HT-150 A 溶着金属部の顕微鏡組織 $(\times 400)$

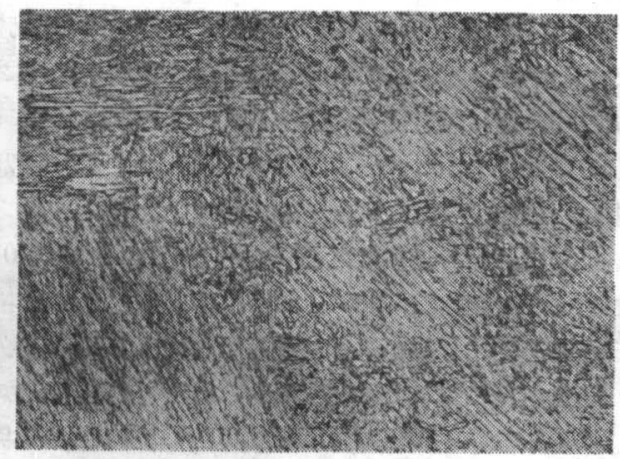

図一24 HT-150 B 溶着金属部の顕微鏡組織 $(\times 500)$

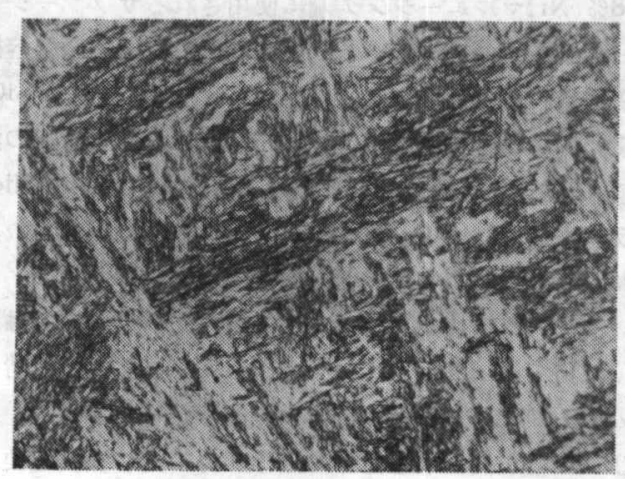

図一25 HT-200 溶着金属部の顕微鏡組織 $(\times 400)$

\section{4 . 3 析出硬化型 $200 \mathrm{~kg} / \mathrm{mm}^{2}$ 級超高張力鋼 (18\%!Ni マルエージング鋼) の溶接}

わが国においてロケットチャンバ用に使用されている 析出硬化型 $200 \mathrm{~kg} / \mathrm{mm}^{2}$ 級超高張力鋼 $(\mathrm{PH}-200)$ は, $18 \% \mathrm{Ni}$ マルエージング鋼に相当する材料である，低合 金マルテンサイト超高張力鋼とことなり, 溶接後 $480^{\circ} \mathrm{C}$ $\times 3 \mathrm{H}$, 空冷の時効処理のみによって溶接継手の強度を出 すととができる.（ただし, 溶接構造物の形状, 応力状 態などにより溶接後 $820^{\circ} \mathrm{C} \times 1 \mathrm{Hr}$ 空冷, $480^{\circ} \mathrm{C} \times 3 \mathrm{Hr}$ 空冷の熱処理が必要な場合あある). この材料の溶接性 はきわめて良好であるが, 溶接施工に当っては, 溶接方 
鈴木, 禾山：ロケットチャンバ用超高張力龬とその溶接

法, 溶接材料, 溶接条件, 時効処理条件なよ゙, の諸問題 があり，また溶接熱影響部については，軟化部が生じる ここなどの問題がある．これらの事項に関し，筆者らが 現在までに解明したことをのべる。

\section{3 .1 溶接方法扐よび溶接材料}

適用できる溶接方法ししては，被覆アーク溶接，サブ マージトアーク溶接, TIG 溶接, MIG 溶接, およびエ レクトロンビーム溶接が考えられる。この超高張力鋼は 溶着金屬の化学成分も母材と同様に極低炭素，低 $\mathrm{Si}$, 低 Mnでなりればならないために，被覆アーク溶接および サブマージドーーク溶接のように，溶融金屬と溶融フラ ックスとの化学治金反灾が，溶着金䀜を支配する溶接法 はフラックスの化学成分がもっとも問題となる。また低 $\mathrm{Si}$ 书よび低 Mn の溶着金盈を形成ささせなければならない ために，Si および Mn による脱酸ができないので， Ti お よび Al てよる脱酸を行なわしめなければならず，しか も溶着金屬に母材亡同程度に $\mathrm{Ti}$ ，および $\mathrm{Al}$ を含有させ なければならないので芯線の Ti および Al の含有量を きわめて多くしておく必要がある，たとえば，2.0〜2.5 \% Ti が被楊アーク溶接の場合に必要であると云われて いる.

$18 \% \mathrm{Ni}$ マルエージング鋼に使用されるサブマージド アーク浴接用のフラックスは従来の一般棈造用鉦の溶接 に使用される $\mathrm{SiO}_{2}$ 含有量の高いフラックスでは, $\mathrm{SiO}_{2}$ の逻元により溶着金瀜の Si 量が増加し，この材料の溶 接には適しないため，最近米国の Linde 社で Low-Silica フラックス $\left(3 \% \mathrm{SiO}_{2}, 60 \% \mathrm{CaO}+\mathrm{Al}_{2} \mathrm{O}_{3}\right)$ が開発され， $18 \% \mathrm{Ni}$ 鎆に適用した試験結果が発表されている11.

被覆ア一ク溶接およびサブマージドアーク溶接では， 被琶材料や使用フラックスを考虑しても必然的偪着金 屬の $\mathrm{Si}$ ，および Mn 量が母材より商くなり，かつ $\mathrm{Ti}$ お よび Al 量が低くなるために，き加めて高い強度を要求 することはむつかしく，てれらの溶接法では引張強さが 約 $170 \mathrm{~kg} / \mathrm{mm}^{2}$ 程度加限界のようである。またじん性も $\mathrm{Si}, \mathrm{Mn}$ 量が高くなるために次にのべる TIG 溶接など に比へて低く，約 $2 / 3$ 活に゙のじん性しか出ない，このよう な観点から, 溶着金蠈の形成過程で, 化学治金反応がは とんごない TIG 溶接およひ MIG 溶接が, この材料の 溶接に適している。溶接能率の点から云えば, MIG 溶 接のほうがはるかに高能率であるが，溶接継手の強度の 点では溶接入熱量が增大すると溶着金属と熱影響部の結 晶粒が粗大化し，張度およびじん性が低下する，また溶 接欠陷の点では，溶接入熱量が低下するとブローホール が入りやすい傾问があり，両者を考愿した適正な溶接条 件を選定しなければならない：しかし適正溶接条件（溶 接入熱量 44,000 Joule/in) で溶接を MIG 溶接の場合
行なっても浴接継手強度は約 $180 \mathrm{~kg} / \mathrm{mm}^{2}$ 程度がほぽ限 界值である ${ }^{12)}$ ，これに対して TIG 溶接では，溶接能率 は低いが，溶接入熱量を低くすることができ，しかる欠 陥のない溶接が可能であり, 溶接継手の強度す, 使用ワ イヤの化学成分を調整することによって約 $210 \mathrm{~kg} / \mathrm{mm}^{2}$ 程度までの強さを得ることができる，TIG溶接に使用さ れるワイヤの化学成分は，母材とほぼ同成尔のものがよ く, Witherell, Corigan おょび Deterren らの実験に よってむ， Ni および Co は母材之同じ程度で，Moは 切欠じん性の点から母材よりもやや低い程度の成分がよ い上報告されている(3). またTiについては，0.4\%以上 必要であり，適正な含有量は母材の成分の upper 側に 合わせればよく，Al についても同様な帣えかたでよい。 このように目材とほぼ同成分のワイヤを用いて TIG 溶 接を行なえば，現状ではすっとも信頼できる溶接継手の 性能を得ることができる．以上のべたようにロケット子 +ンバ用としての 18\% Ni マルエージング鉡の溶接に は，TIG 溶接がすっとも適しておるようで米国において す，乙の種超高張力鋼を用いたロケットチ+ンバには， ほとんど TIG 溶接方式が操用され成功をおざている ようである。

\section{3 .2 溶接性}

この超高張力鋼の溶接性はきわわてよく，低合金マル テンサイト超高張力銅のような溶接割狆むほとんど見ら 机ず；予熱なしで TIG 溶接が可能である。 またとくに 拘束力の高い部分の溶接に当っても，適正な溶接条件で 溶接を行なえば予熱なしでも溶接割れは発生しない.

\section{3 .3 溶接熱影響}

この材料の溶接熱影響部は，一般の溶接構造用低合金 マルテンサイト超高張力鋼などとととなった現象を吕す る.すなわち, 溶接のままの状態ではボンド部から少し はなれた部分に図一26に示すように溶接熱によって時効 便化した硬化部が生じる. 溶接後 $480^{\circ} \mathrm{C} \times 3 \mathrm{Hr}$ の時効 処理を行なうと，図一27に示すように，熱影響部にこの 時効好理によって硬化しない領域，すなわち乾化部が生 じることがわかる：ての軟化部の挙動を調べるために， 小試験片に溶接熱影響部の熱サイクルを再現させて，そ れらのかたさを調べ，最高加熱温度と，かたさとの開係 を求めたが，その結果は図一28に示すとおりである.こ の結果からわかるように，溶接熱によって $640 \sim 740^{\circ} \mathrm{C}$ に加熱された領域は， $480^{\circ} \mathrm{C} \times 3 \mathrm{Hr}$ の時効好理によって あほとんど硬化しない，また最高加熱温度が高い粗粒域 は，時効処理によって硬化するが，母材之同程度のかた さには達しない，図一27に示した実際の溶接継手の場合 と図一28に示した再現試験の場合とを比較すると，実際 の溶接継手に生じる軟化域は，640～ $740^{\circ} \mathrm{C}$ に加熱され 


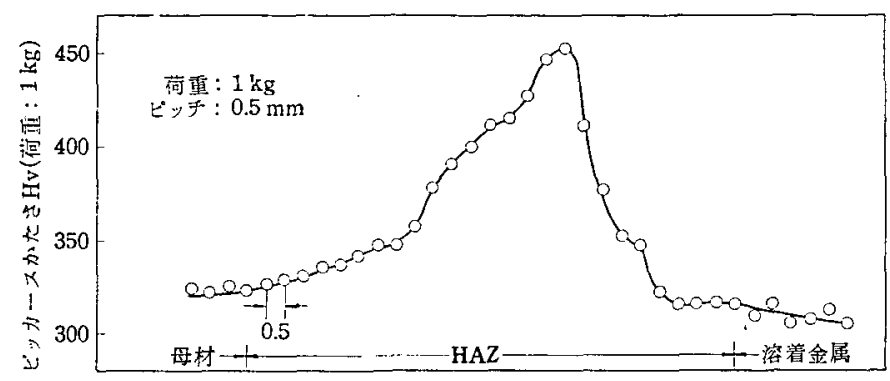

図一2B PH-200 溶接部のかたさ分布（溶接のまま）

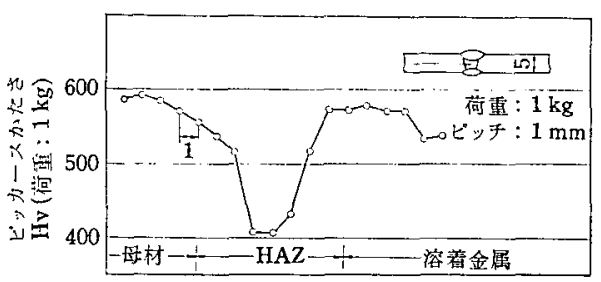

図一27 PH-200 溶接部のかたさ分布 (溶接後 $480^{\circ} \mathrm{C} \times 3 \mathrm{Hr}$ 時效処理)

た部分であると考えられる。また粗粒域では，一サイク ルの熱サイクルを受けた場合には，時効後において母材 上りもかたさが低くなることは図一28によってわかる が，図一27の上うに多層溶接を行なった場合には，軟化 現象は生じない.

$640 \sim 740^{\circ} \mathrm{C}$ に加熱された領域の軟化郳象について， さらに检討するために, 最高加熱温度 $690^{\circ} \mathrm{C}$ の場合の急 速加熱冷却過程の熱膨脤曲線を描いた結果を図一29に示 す.とれからわ加ううに，加熱時には約 $640^{\circ} \mathrm{C}$ から， オーステナイト変態它始め, 一部オーステナイト組織と なった状態で掵却されるために，そのオーステナイトが きわめて安定なすのであり，室温まで冷却してもマルテ ンサイトに変態さず，オーステナイト組織として残留す
る.このために時初処理によってる析出硬化をおこさな いものと考えられる.

次に溶接条件上ボンド部の組織,およびかたさとの関 係を調べるために，小試験片を $1350^{\circ} \mathrm{C}$ に急速加熱し， 種々の椧却条件で领却させ冷却過程における变態と, 冷 却後のかたさとの関係を求めたが, $800^{\circ} \mathrm{C}$ から $500^{\circ} \mathrm{C}$ までの冷却時間が約 $800 \mathrm{sec}$ 以内の冷却条件では，す心゙ てマルテンサイト組織上なり, その Ms 点は約 $200^{\circ} \mathrm{C}$ であり，図一30に示すように熱サィクルのままの状 態でのかたさす，冷却時間に無関係に $\mathrm{H}_{\mathrm{V}} 335,480^{\circ} \mathrm{C}$ $\times 3 \mathrm{Hr}$ 時效処理後においても同様に $\mathrm{H}_{\mathrm{V}} 565$ である. このようにボンド部のかたさは，冷却時間による影響は ほとんよ゙ないと考えてよいが, 冷却が沟るやがなると 結晶粒が粗大化し，降伏強度およびじん性に影蠁してく る上思われる．以上の点からこの超高張力鋼の溶接熱影 響部に生じる軟化域は溶接継手の強度之密接な関係があ り，軟化域の影響の少ない溶接施工扰よび工作法を採用 せねばならない。

\section{3 .4 溶接継手の性能}

溶接継手の機械的性質は，使用板厚，使用ワイヤの化 学成分, 溶接諸条件, および溶接後の蓺処理によってと となってくる。

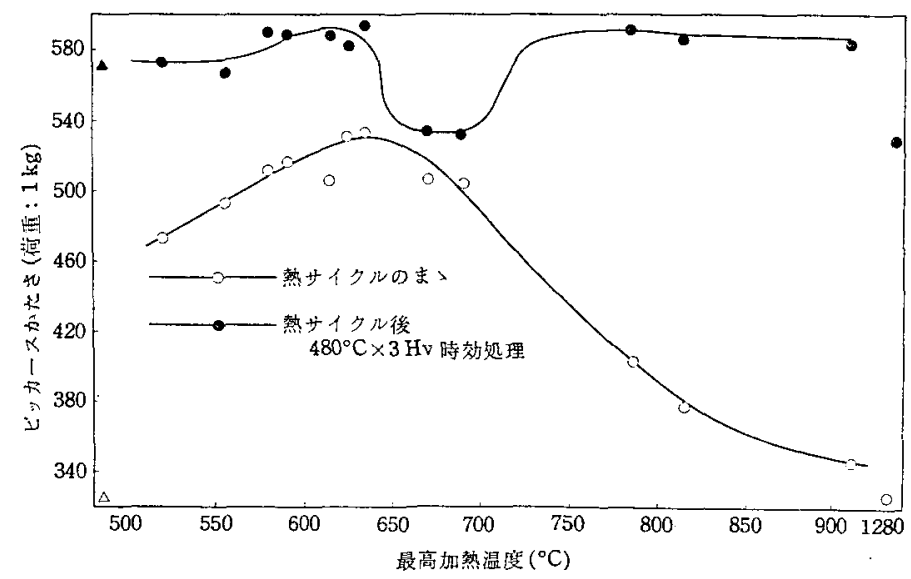

図一28 溶接熱サイクルによる最高加熱温度とかたさとの関係 


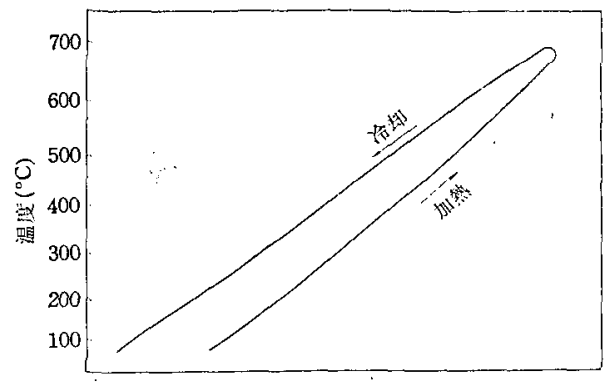

搕朖

図一29 㵊高加熱温度 $690^{\circ} \mathrm{C}$ の場合の熱膨脤 温線

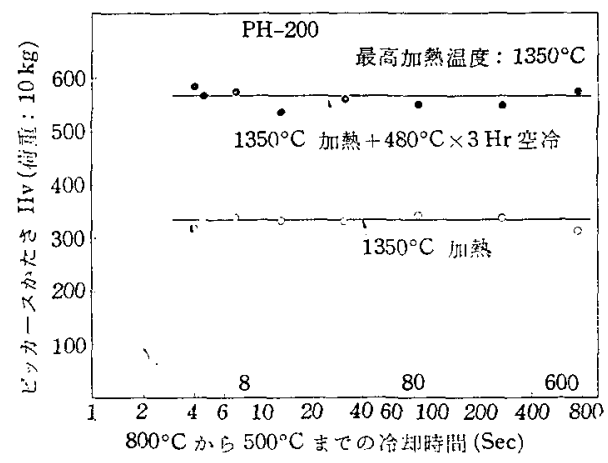

図一30 $1350^{\circ} \mathrm{C}$ に加熱された熱影響部のかた さと $800^{\circ} \mathrm{C}$ 加ら $500^{\circ} \mathrm{C}$ まで冷却時 間亡の関係

表一14に，使用板厚 $1.7 \mathrm{~mm}, 6 \mathrm{~mm}$ および $15 \mathrm{~mm} の$ TIG 溶接継手の引㖘試験結果を一括して示すが，溶接施 工条件が邀正であれば，軟化部の影響をなくすることが 可能であり，また溶接後 $820^{\circ} \mathrm{C} \times 1 \mathrm{H}$ 空冷， $480^{\circ} \mathrm{C} \times 3 \mathrm{H}$ 空冷の熱姏理を行なうとなくなり，さらに継手强度を上 げることができる，溶接継手效率ししては，母材の強度 程度によってことなるが，いま贯材の引張強さが $200 \mathrm{~kg}$ $/ \mathrm{mm}^{2}$ 以上と考えると, 表一 14 加らわかるうに, 浴接 施工条件が適正であれば継手効率は95\%以上が可能であ る.ただし，軟化部の影響が生じるような溶接施工条件 で行なえば，継手効率は約85\%となる.

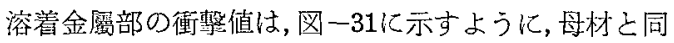

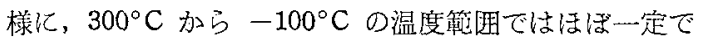
あり䑁移現象はない。衝撃值は，使用するワイヤの製造 方法によってととなってくる.すまわち，大気溶解材の ワイヤを用いた場合は， $1 \mathrm{~kg}-\mathrm{m} / \mathrm{cm}^{2}$ 以下の衝謷值しか 得られないのに対して，真空溶解材のワイヤを用いる 之, $1.7 \mathrm{~kg}-\mathrm{m} / \mathrm{cm}^{2}$ 以上の衙靔值を得るこ上ができ，溶 着金属のじん性の点から五えば, 点空溶解したワイヤが 適している。
表一15に，母材の項でのべたと同㥞な ASTM の切欠 引張試験を行ない破塤じん性 (Fracture Toughness) を 溶接継手に刘して（切欠は溶着金属中央に入机た）求め た結果を一括して示した. 表一15からわかるように， 前に表一6に示した母材の $K_{c}$ 値よりあやや低い. こ のように溶着金属部の衝整値，および $K_{c}$ 值は，母材よ りむ低いので溶着金属部は，不安定破填が生じやすい特 性を有しており応力集中源となる溶接欠陌に対してはと くに注意を払わなければならない。

図一 32 には，板厚 $1.7 \mathrm{~mm}$ と $6 \mathrm{~mm}$ の溶接部のマク 口組織を示す，溶接後仙いて， $820^{\circ} \mathrm{C} \times 1 \mathrm{H}$ 空泠後 480 ${ }^{\circ} \mathrm{C} \times 3 \mathrm{H}$ 時效処理を行なうと, 溶接部は均一した組織之 なり，熱影響部に生じる軟化域がなくなることが，殏 -32から屯わかる. 溶接部の影微鏡組織を図一33に示古 が，熱影響部は，母材の千密な組織に比へて絬罪粒が粗 大化している，溶着金属部は，ての顕徽鏡組織加らもわ かる上うに，結昆精界にオーステナイトが牫留してい る。この溶着金属部に生じる残留オーステナイトの影響 については，まだ現状では解明されていない。

表-14 PH-200 溶接継手の強度

\begin{tabular}{|c|c|c|c|}
\hline$(\mathrm{mm})$ & 熱 処 罢 & $\begin{array}{c}\text { 引) 张 } \\
\left(\mathrm{kg} / \mathrm{mm}^{2}\right)^{2}\end{array}$ & 破 断售置 \\
\hline \multirow{2}{*}{1.7} & $\mathrm{~W} \rightarrow \mathrm{S} \rightarrow \mathrm{A}$ & $\begin{array}{l}195.0 \\
195.4\end{array}$ & 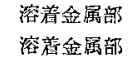 \\
\hline & $\mathrm{W} \rightarrow \mathrm{A}$ & $\begin{array}{l}191.4 \\
189.3\end{array}$ & $\begin{array}{l}\text { 溶盖金属部 } \\
\text { 溶着金属部 }\end{array}$ \\
\hline \multirow{2}{*}{6.0} & $W \rightarrow S \rightarrow A$ & $\begin{array}{l}205.3 \\
202.7\end{array}$ & $\begin{array}{l}\text { 溶䈍金属部 } \\
\text { 溶普金属部 }\end{array}$ \\
\hline & $W \rightarrow A$ & $\begin{array}{l}192.1 \\
195.5\end{array}$ & 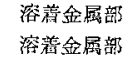 \\
\hline 15 & $\mathrm{~W} \rightarrow \mathrm{S} \rightarrow \mathrm{A}$ & $\begin{array}{l}196.6 \\
191.1\end{array}$ & $\begin{array}{l}\text { 溶着金属部 } \\
\text { 渗着金属部 }\end{array}$ \\
\hline
\end{tabular}

$\mathrm{W}:$ 溶接

$\mathrm{S}: 820^{\circ} \mathrm{C} \times 1 \mathrm{Hr}$ 空冷

A : $480^{\circ} \mathrm{C} \times 3 \mathrm{Hr}$ 時效処理

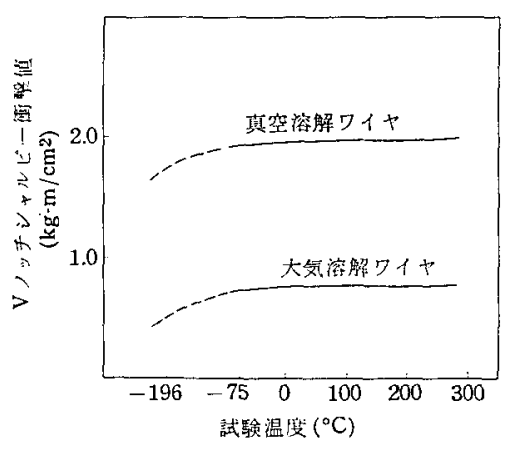

図-31 PH-200 溶着金屬部の V ノッ千 シャルピー衝撃試験結果 
表-15 PH-200 溶着金属の Kc 值

\begin{tabular}{|c|c|c|c|c|c|c|c|c|c|c|}
\hline $\begin{array}{c}\sigma \mathrm{y} \\
\left(\mathrm{kg} / \mathrm{mm}^{2}\right)\end{array}$ & $\begin{array}{c}\mathrm{W} \\
(\mathrm{mm})\end{array}$ & $\begin{array}{c}\mathrm{T} \\
(\mathrm{mm})\end{array}$ & $\begin{array}{c}\mathrm{a} \\
(\mathrm{mm})\end{array}$ & $\begin{array}{c}\text { 最大荷重 } \\
(\mathrm{kg})\end{array}$ & $\begin{array}{c}\sigma \mathrm{g} \\
\left(\mathrm{kg} / \mathrm{mm}^{2}\right)\end{array}$ & $(\sigma \mathrm{g} / / \sigma \mathrm{y})^{2}$ & $\pi \sigma / \mathrm{W}$ & $q$ & $\checkmark \overline{\mathrm{qW}}$ & $\frac{\mathrm{kg} v \overline{\mathrm{mm}}}{\mathrm{mm} \mathrm{m}^{2}}$ \\
\hline 175 & 30.05 & 1.03 & 2.93 & 3590 & 116.0 & 0.44 & 0.306 & 0.52 & 3.95 & 458 \\
\hline 175 & 30.00 & 1.02 & 2.93 & 3010 & 98.4 & 0.31 & 0.304 & 0.46 & 3.71 & 365 \\
\hline 194 & 34.10 & 1.18 & 10.85 & 3630 & 58.8 & 0.092 & 0.995 & 1.65 & 7.50 & 440 \\
\hline 194 & 34.00 & 1.71 & 9.05 & 3990 & 65.9 & 0.116 & 0.836 & 1.26 & 6.54 & 431 \\
\hline 193 & 99.75 & 4.99 & 20.10 & 17200 & 34.5 & 0.032 & 0.631 & 0.84 & 9.16 & 316 \\
\hline 193 & 99.75 & 5.01 & 19.70 & 15500 & 31.0 & 0.026 & 0.618 & 0.82 & 9.04 & 280 \\
\hline
\end{tabular}

$\sigma \mathrm{y}:$ 耐力

$\mathrm{W}$ : 試験片の巾

$\mathrm{T}:$ " 板厚

a : スロークラックの長さ

$\sigma \mathrm{g}$ : 破断時の全体の平均応力（切欠きがないと考えた場合の平均応力）

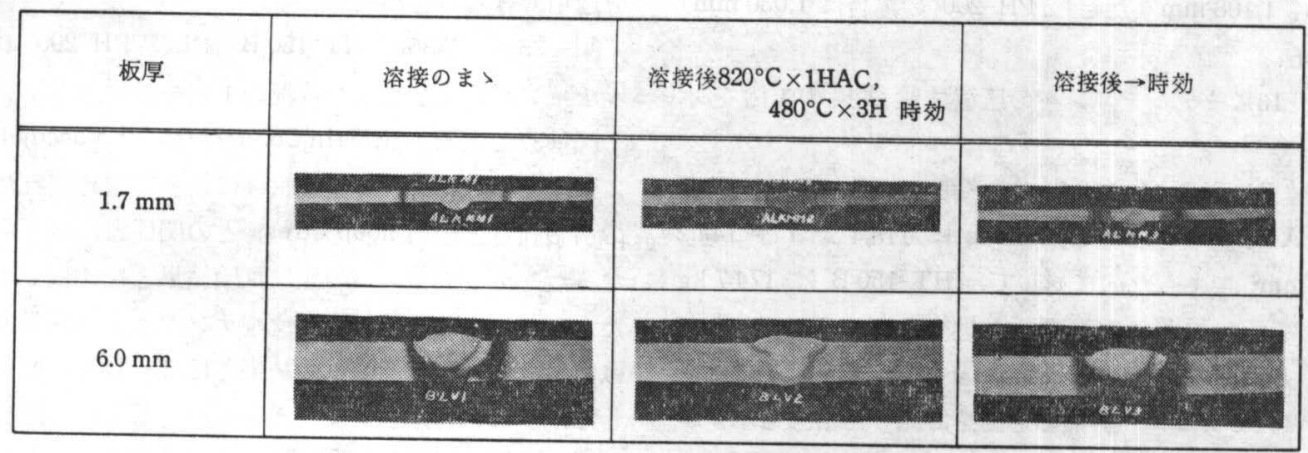

図一32 PH-200 溶接部のマクロ組織

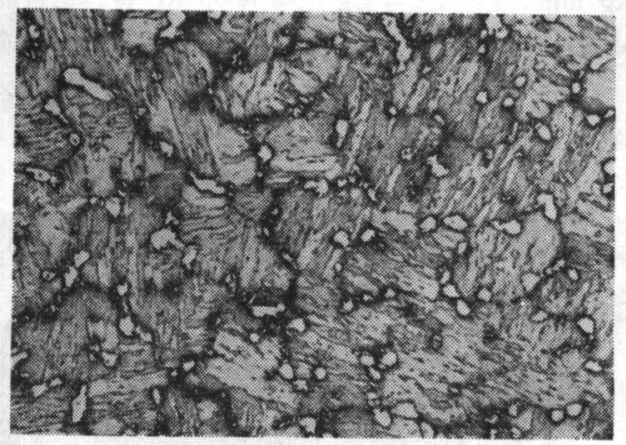

溶着金属部 $(\times 500)$

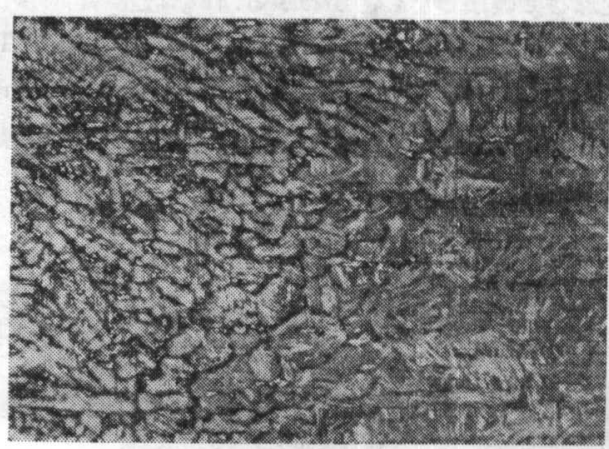

境 界 部 $(\times 100)$

図-33 PH-200 溶接部の顕微鏡組織

\section{5. 小型モデルチャンバの 圧壤試験}

ロケットチャンバに超高張力鋼を適用する場合には, 母材試験, 溶接試験および破壊じん性試験などによって その適応性を一応検討できるが，さらにそれらが総合さ れた構造物としての適応性を検討するためにモデルチャ ンバの圧壊試験を行なわなければならない，その結果に
よって, その材料の適応性, 工作法の適否などが明らか になり, かつロケットチャンバとしての性能が確認でき るのである．とのような見地加ら，筆者らは 150 200 $\mathrm{kg} / \mathrm{mm}^{2}$ 級超高張力鋼の各種:のモデルチャンバを製作 し, それらの压壊試験を行なった。使用材料は, 表一 3 に示すどとく，150 200 kg/mm ${ }^{2}$ 級低合金マルテンサ イト超高張力鋼（HT-150 A, B および:HT-200) と析出 硬化型 $200 \mathrm{~kg} / \mathrm{mm}^{2}$ 級超高張力鋼（PH-200, 18\% Ni ? 
鈴木, 下山：ロケットチャンバ用超高張力鋼とその溶接

表一16 モデルチャンバーの圧壊試験結果の例

\begin{tabular}{|c|c|c|c|c|c|c|}
\hline モデルの型 & 料 & $\begin{array}{l}\text { 然の引張 } \\
\text { 強ざ } \\
\left(\mathrm{kg} / \mathrm{mm}^{2}\right)\end{array}$ & $\begin{array}{l}\text { 板 厚 } \\
(\mathrm{mm})\end{array}$ & $\begin{array}{l}\text { 破壤匠力 } \\
\text { (kg/cm2) }\end{array}$ & $\begin{array}{c}\text { 破壤時の } \\
\text { 椞萛応力 } \\
\left(\mathrm{kg} / \mathrm{cm}^{2}\right)\end{array}$ & 破壞位買 \\
\hline \multirow{2}{*}{ A } & HT-150A & 165 & 2.8 & 160 & 118.4 & 溶接 部 \\
\hline & HT -200 & 201 & 2.8 & 145 & 107.2 & 母 材 \\
\hline \multirow{4}{*}{ B } & HT-150A & 165 & 2.8 & 195 & 144.2 & 母 材 \\
\hline & HT-150B & 166 & 2.0 & 168 & 174.7 & 溶 接 部 \\
\hline & HT -200 & 201 & 2.8 & 159.5 & 118.0 & 溶 接 部 \\
\hline & PH-200 & 200 & 2.8 & 250 & 178.8 & 溶 接 部 \\
\hline
\end{tabular}

ルエージング鋼に相当）である. モデルチャンバの寸法 は内径 $420 \mathrm{~mm} \phi$ (ただし $\mathrm{PH}-200$ の場合は $406 \mathrm{~mm} \phi$ ) で, Type A はチャンバ全長が $1,903 \mathrm{~mm}$, Type B が 同じく 1,108 mm（ただし,PH-200 の場合は 1,030 mm) である。

表一16にモデルチャンバの圧壊試験結果の1例を示 す.

この結果によると, $150 \mathrm{~kg} / \mathrm{mm}^{2}$ 級超高張力鋼では, HT -150 A は圧壊時の hoop stress は 118.4 および 144.2 $/ \mathrm{kg} / \mathrm{mm}^{2}$ であったのに対して，HT-150 B は $174.7 \mathrm{~kg}$ $\mathrm{mm}^{2}$ を示し, きわめて優秀な性能を有していることが わかった. 図-34に HT-150 B のモデルチャンバの水圧 時においてチャンバ各部の応力を計測した結果を示すが （符号 $3 ， 4 ， 13,14$ は中央部， 7,8 は端部）hoop stress が約 $130 \mathrm{~kg} / \mathrm{mm}^{2}$ 程度から降伏を開始し, 著しく そ性変形して破壊したことがわかる。

低合金マルテンサイト $200 \mathrm{~kg} / \mathrm{mm}^{2}$ 級超高張力鋼 HT -200 は，压壊 hoop stress が107.2および $118.0 \mathrm{~kg} / \mathrm{mm}^{2}$ であり，降伏点よりあはるかに低い応力レベルで破壊 し，ロケットチ+ンバには適用できないことが明らかに なった。

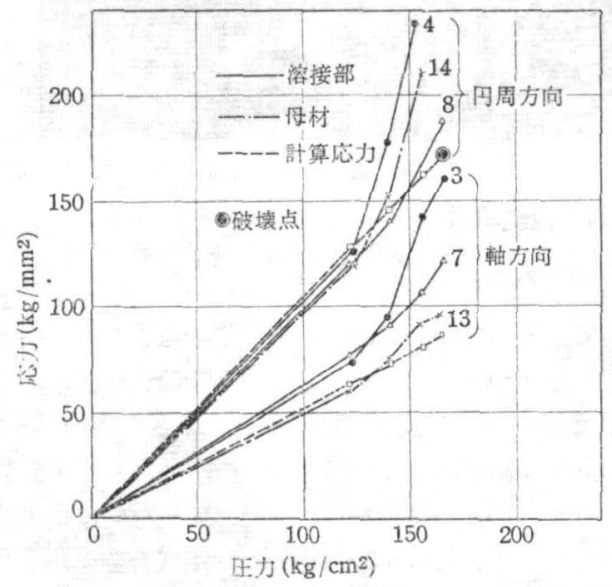

図一-34 HT-150 B のモデルチャンパー水圧試 験における圧力と応力との関係
析出硬化型 $200 \mathrm{~kg} / \mathrm{mm}^{2}$ 級超高張力鋼 $\mathrm{PH}-200$ は, 压 壊 hoop stress $178.8 \mathrm{~kg} / \mathrm{mm}^{2}$ を示し(軟化部で破断), 継 手効率を考慮するととによって，ロケットチャンバに十 分適用できることが確認できた。

図一35および36に HT-150 B および PH-200 のモデ ルチャンバの压壊された状況の 1 例を示す.

図一37に米国の Martin Co. で行なった Vascojet 1000 についてのチャンパの圧壊試験によって求められた母材 の引張強さと圧壊 hoop stress との関係と, 筆者らが行 なったモデルチャンバの圧壊試験結果とを比較して示し た.これによると, 低合鉝マルテンサイト超高張力鋼で は, Martin Co. での試験結果とほほ一致した傾向を示 した.すなわち、ロケットチャンバとしての性能を得る ための限界の引張強さは $175 \mathrm{~kg} / \mathrm{mm}^{2}$ であることが明ら かになった。これに反して $\mathrm{PH}-200$ は，引張強さが 175 $\mathrm{kg} / \mathrm{mm}^{2}$ 以上になっても圧壊 hoop stressは低合金マル テンサイト超高張力鋼のように低下しないことが確認で き, $200 \mathrm{~kg} / \mathrm{mm}^{2}$ 級の性能を有するロケットチャンバに 対しては，PH-200 か適しているととがわかった。

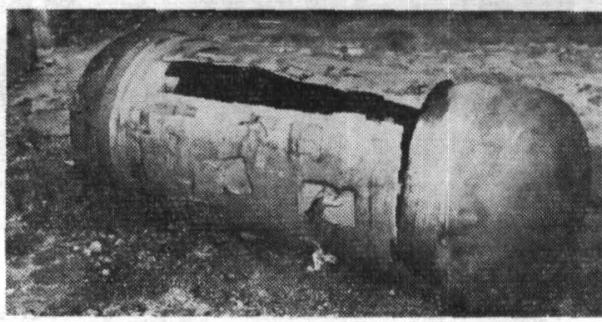

図一35 HT-150B モデルチャンバーの压壊状況

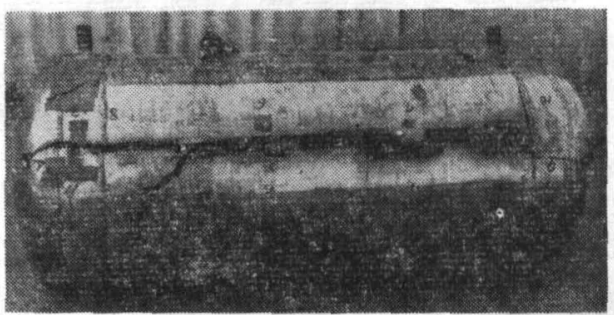

図一36 PH-200 モデルチャンバーの圧壊状況 


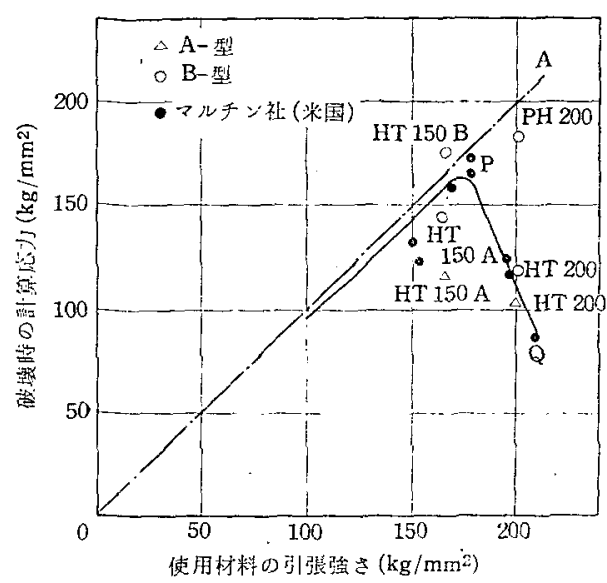

図一37 使用材料の引張強さ之破壊時の計算応 力との関係

この死壊試験の結果によって，東京大学宇宙航空研究 所の L-3 型1号ロケットの第 3 段目のチャンバには, $300 \mathrm{M}$ を改良した HT-150B が，また L-3型 3 号口ケ ットの第3段目のチャンバには，PH-200 が採用される ようになったすのたある。

\section{6 . 今後の問題}

わが国における宇宙観测用のロケットチャンバに対し $\tau, 85 \mathrm{~kg} / \mathrm{mm}^{2}$ 級高張力銅にはじまり，100 kg/mm², $150 \mathrm{~kg} / \mathrm{mm}, 200 \mathrm{~kg} / \mathrm{mm}^{2}$ 級超高張加錀と次々に八イレ ベルのものが灾用されてきたが，今後さらにロケットの 高性能化によもないチャンバ重量の軽減化が強く要望さ れており，そのた加には，200 $\mathrm{kg} / \mathrm{mm}^{2}$ 以上の超高張力 鍼の開発たとえばオースフォーミング鋼の開発やある いは，破埣じん性の著しく高い超高張力鋼を開発し，そ の溶接施工法を確立して安全率を下げ，ロケットチャン バの軽量化を行なうということも考えられている。

さらに今後，ロケットの大型化に伴なう大型ロケット チャンバ用の超高張鋼力の開発亡工作法の確立委急務な 問題である。

\section{7.むすび}

わが国における宇宙観测用ロケットチャンバの開発 は，東京大学宇宙航空研究所上三菱重工業株式会社神戸 研究所と神可造船所が一体となり，昭和34年度に $85 \mathrm{~kg}$ $/ \mathrm{mm}^{2}$ 級高張力鋼を採用して以来, $100 \mathrm{~kg} / \mathrm{mm}^{2}, 150 \mathrm{~kg}$ $/ \mathrm{mm}^{2}$ 战よび $200 \mathrm{~kg} / \mathrm{mm}^{2}$ 級超高張力鉵を次々に開発 し，ロケットチャンバに採用し成功をおさめた。

本稿は, 筆者らの行なったこれら一連の開発研究結果
を主体にしてのい゙たるのである。

なお，大型ロケットチャンバ用の厚板超高張力鋼に関 する詳細な研究結果は，本稿では省略させていただいた が，てれについては次の機会に報告する所存である.

またロケットチャンバ用材料は，超高張力鋼のみでは なく $\mathrm{Ti}$ 合金14や $\mathrm{Al}$ 合金があり，それぞ机適した口ケ ットに採用されている. これらの研究結果についてす, 同様に報告させていただく所存である。

最終に，筆者らの研究に対してつ权に懇切な御指導を いただいた專京大学宇宙航空研究所教授系川英夫博士， 教授森大吉郎博士，同じく東京大学工学部教授安藤良夫 博士，および三菱重工業棶式会社神戸造船所調查役高木 乙麿博士に深く感謝の意在表する. また等者らの研究に 対して御協力いただいた川渏製鉄株式会社, 株式会社神 戸製鋼所および栋式会社日本製鋼所の関係諸氏に深く感 㖣する。

\section{参考 文 献}

1) 西茂, 却水和久，下山仁一，萄地萃夫，“150 - 200 kg/mm2 級

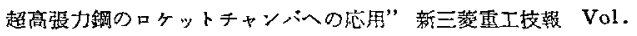
6. No. 1 (1963)

2）哙木和久, 下山た一, 福客勝敏；“ロケットチャンバ用 150 200

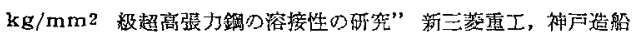
所研究報告 $3 Q$ Q G02638 (1963)

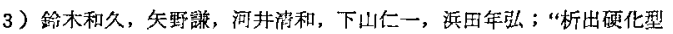

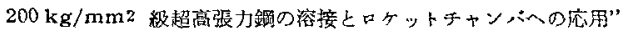
三落重工技報 Vol. 2, No. 1 (1965)

4) H.R. Smith, R.E. Anderson and J.T. Bingham ; "A User Evaluates MaragingSteels" Metal Progress Nov. 1962 , p. 103 105

5) "Fracture Testing of High Strength Steel Materials" A Report of Special ASTM Committee (1960-1), ASTM Balletin, p. $29 \sim 40$

6) G.R. Speich ; "Age-Hardening of Fe 20 Pct Ni Martensites" Trans. Matallurgical Society of AIME, Vol. 227 (1963-12), p. 1426 1432

7) S. Floreen, R.F. Decker; "Heat treatment of $18 \% \mathrm{Ni}$ Maraging Steel" Trans. of the ASM, Vol. 5 (1962) p. $518 \sim 530$

8) R. Blower, G. Mayer; "Austenitic Stainless Steels Precipitation Hardned with Titanium" J. of the Iron and Steel Inst. (1963-11) p. 933 943

9) H.W. Mishler, R.E. Monroe and P.J. Riephel ; "Stu dies of Hot Cracking in High-Strength . Weld Metals" W.J. (1961-1) 1s $\sim 7 \mathrm{~s}$

10) P.J. Rieppel; "Welding Solid-Fuel Rocket Motor Cases" Metal Progress (1960 i) p. 105 110

11) Thomas L. Colers; "New Low-Silica Compositions of Submerged.Arc Welding" W.J. Feb. 1965 p. 72s $\sim 78 \mathrm{~s}$

12) D.A. Canonico; "Gas Metal-Arc Welding of $18 \%$ Nickel Maraging Steel" W.J. Oct. 1964 433s $\sim 442 \mathrm{~s}$

13) R.M. Evans and R.E. Monroe; "The Current Status of the Welding of Maraging Steels" Eattle Memorial Institute, Oct. 1963

14）鉿木和久，下山ヒ一，捠田年引；“チタン合金の溶接とロタットチ

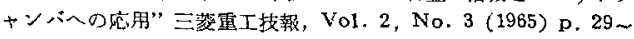
38 